\title{
Identification of developmentally toxic drinking water disinfection byproducts and evaluation of data relevant to mode of action ${ }^{2}$
}

\author{
Joan Colman ${ }^{\text {b }}$, Glenn E. Rice ${ }^{\mathrm{a}, *}$, J. Michael Wright ${ }^{\mathrm{a}}$, E. Sidney Hunter III ${ }^{\mathrm{c}}$, Linda K. Teuschler ${ }^{\mathrm{a}}$, \\ John C. Lipscomb ${ }^{\text {a }}$, Richard C. Hertzberg ${ }^{\mathrm{d}}$, Jane Ellen Simmons ${ }^{\mathrm{c}}$, Margaret Fransen ${ }^{\mathrm{b}}$, \\ Mark Osier ${ }^{\mathrm{b}}$, Michael G. Narotsky ${ }^{\mathrm{c}}$ \\ a National Center for Environmental Assessment, Office of Research and Development, U.S. Environmental Protection Agency, Cincinnati, OH 45268, USA \\ ${ }^{\mathrm{b}}$ Chemical, Biological and Environmental Center, SRC, Inc., Syracuse, NY 13212, USA \\ ${ }^{c}$ National Health and Environmental Effects Research Laboratory, Office of Research and Development, U.S. Environmental Protection Agency, Research Triangle Park, NC 27711, USA \\ d Department of Environmental and Occupational Health, Rollins School of Public Health, Emory University, Atlanta, GA 30322, USA
}

\section{A R T I C L E I N F O}

\section{Article history:}

Received 30 October 2008

Revised 22 April 2010

Accepted 22 April 2010

Available online 4 February 2011

\section{Keywords:}

Mode of action

Developmental toxicity

Drinking water disinfection byproducts

(DBPs)

Spontaneous abortion

Full-litter resorption

Cardiovascular malformation

Neural tube defect

Low birth weight

\begin{abstract}
A B S T R A C T
Reactions between chemicals used to disinfect drinking water and compounds present in source waters produce chemical mixtures containing hundreds of disinfection byproducts (DBPs). Although the results have been somewhat inconsistent, some epidemiological studies suggest associations may exist between DBP exposures and adverse developmental outcomes. The potencies of individual DBPs in rodent and rabbit developmental bioassays suggest that no individual DBP can account for the relative risk estimates reported in the positive epidemiologic studies, leading to the hypothesis that these outcomes could result from the toxicity of DBP mixtures. As a first step in a mixtures risk assessment for DBP developmental effects, this paper identifies developmentally toxic DBPs and examines data relevant to the mode of action (MOA) for DBP developmental toxicity. We identified 24 developmentally toxic DBPs and four adverse developmental outcomes associated with human DBP exposures: spontaneous abortion, cardiovascular defects, neural tube defects, and low birth weight infancy. A plausible MOA, involving hormonal disruption of pregnancy, is delineated for spontaneous abortion, which some epidemiologic studies associate with total trihalomethane and bromodichloromethane exposures. The DBP data for the other three outcomes were inadequate to define key MOA steps.
\end{abstract}

\section{Introduction}

Chemical disinfection of drinking water has reduced significantly the incidence of infectious waterborne disease, but reactions of disinfectants such as chlorine with natural organic matter in source waters produce chemical mixtures composed of hundreds of different disinfection byproducts (DBPs) (Krasner et al., 2001, 2006; Miltner et al., 1990; Richardson, 1998; Richardson et al., 1999, 2000a,b, 2003, 2008; Weinberg, 1999; Weinberg et al., 2002). Although inconsistent results have been reported across different epidemiological studies, some studies have reported associations between DBP exposure and increased risk of adverse developmental outcomes including term low

\footnotetext{
is Notice. On behalf of all authors, the corresponding author declares there is no conflict of interest in this study. The views expressed in this paper are those of the authors and do not necessarily reflect the views and policies of the U.S. Environmental Protection Agency. Mention of trade names or commercial products does not constitute endorsement or recommendation for use.

* Corresponding author at: U.S. Environmental Protection Agency, National Center for Environmental Assessment, 26 West M.L. King Dr., Cincinnati, OH 45268, USA. Fax: +1 15134872539 .

E-mail address: rice.glenn@epa.gov (G.E. Rice).
}

birth weight or small for gestational age births (Gallagher et al., 1998; Hoffman et al., 2008; Infante-Rivard, 2004; Lewis et al., 2006, 2007; Wright et al., 2003, 2004), birth defects such as cardiovascular and neural tube defects (e.g., Cedergren et al., 2002; Chisholm et al., 2008; Dodds and King, 2001; Hwang et al., 2008; Klotz and Pyrch, 1998, 1999; Nieuwenhuijsen et al., 2008), spontaneous abortion (Savitz et al., 1995, 2005, 2006; Waller et al., 1998, 2001), and stillbirths (Dodds et al., 2004; Toledano et al., 2005). Because such epidemiological associations do not necessarily imply causality, developmental toxicity studies of individual DBPs have been undertaken (summarized in Klinefelter et al., 2001 and in this paper) to test the hypothesis that exposures to DBPs cause developmental effects. A number of individual DBPs cause adverse developmental effects in mammalian bioassays; however, to date, these toxicological studies do not identify any single DBP with sufficient potency to account for the relative risk estimates reported in the epidemiological literature. This observation has led some to hypothesize that exposures to mixtures of DBPs are associated with the developmental outcomes reported in epidemiological studies and that this hypothesis could be examined through toxicological experiments with DBP mixtures and components using methods for mixtures risk assessment (Simmons et al., 2002, 2004, 
2008; Teuschler and Simmons, 2003). To comply with developmental study guidelines (U.S. EPA, 1991), the DBP exposure levels employed in these bioassays are typically significantly higher than human oral DBP exposures.

Evaluations of human health risks associated with exposure to chemical mixtures rely on component or whole mixture methods (ATSDR, 2004; U.S. EPA, 1986, 2000a). For exposure to chemicals in the low dose region, where interactions are deemed unlikely to occur, two relatively simple component methods (dose addition and response addition) are used in risk assessments conducted at a screening or intermediate level (U.S. EPA, 2000a). Dose additive models are used to estimate risks posed by toxicologically similar chemicals that exhibit the same toxic mode of action (MOA) and response additive models are used to estimate risks posed by toxicologically independent chemicals that affect the same target organ or cause the same illness (e.g., cancer) but exert these effects through different toxic MOAs (Feron and Groten, 2002; U.S. EPA, 2000a). Thus, knowledge of MOA, or an assumption about the similarity or dissimilarity of MOA, is required for a componentbased risk assessment. The MOA is the set of biological events (the key events) at the target tissue or target organ, and/or related tissues that influence the target organ, leading to a toxicologic outcome. MOA thus implies a general understanding of key toxicodynamic events leading to the outcome, but is not as stringent as mechanism of toxicity (Teuschler et al., 2004; U.S. EPA, 2000a, 2003, 2005). In addition to knowledge about MOA, knowledge of critical targets of toxicity can also be important determinants of other component approaches to mixtures risk assessment. Under the hazard index approach and interactionbased hazard index (U.S. EPA, 2000a), dose addition is assumed based on common target organ toxicity of the components.

Absent knowledge of MOA, information identifying the site of insult (critical tissue) for developmental toxicants (e.g., maternal tissues or fetal tissues) is valuable in grouping chemicals for risk assessment. While the MOA may include dosimetric descriptions, especially accumulation of toxic metabolites in target tissues, nearly all studied DBPs have short half-lives. Some are bioactivated to toxic metabolites while others are detoxicated; some are reduced to two-carbon molecules that are transformed via the Krebs cycle to become incorporated in normal cellular constituents (ILSI, 1999; Lipscomb et al., 2009). Some, like the haloacetonitriles, are reactive to the point that their distribution from blood and tissues may be limited by protein binding. Accordingly, in this paper, metabolism and distribution data are discussed in the text and summarized in the last column of the summary tables when potentially relevant to an MOA. While MOA descriptions for systemic toxicity other than reproductive and developmental affects have been developed for some DBPs, MOA descriptions or even analysis of sites of insult for developmental toxicity have yet to be accomplished for the majority of the DBPs.

The purpose of this review and evaluation is to identify DBPs that have been shown to cause developmental effects, and to evaluate the potential MOA(s) and/or sites of toxic insult for different developmental effects. Four outcomes of concern were targeted based on human health effects identified in the epidemiologic studies of treated drinking water and DBPs: spontaneous abortion, cardiovascular defects, neural tube defects, and low birth weight/intrauterine growth retardation. We evaluated the literature using established criteria for causality, adequacy of developmental toxicity studies, and identification of potential MOA.

\section{Methods}

We performed an extensive literature search to identify DBPs that had been examined for developmental toxicity in humans or mammalian test species and to identify MOA data relevant to developmental toxicity for these DBPs. The starting point for compound selection included the following DBP classes, individual members of these classes, and other chemicals (name, synonyms and CASRN): trihalomethanes, haloacetic acids, haloacetonitriles, halopropanones, nitrosamines, chlorine dioxide, chlorate, chlorite, chloral hydrate, chloropicrin, bromate, formaldehyde, and MX (3chloro-4-(dichloromethyl)-5-hydroxy-2(5H)-furanone). Literature searches included DART, PubMed, and Toxic Substances Control Act Test Submissions as well as secondary sources such as the Integrated Risk Information System (IRIS), U.S. Environmental Protection Agency (EPA) reports, Agency for Toxic Substances and Disease Registry (ATSDR) toxicological profiles, and literature reviews and analyses (e.g., Bove et al., 2002; Graves et al., 2001; Nieuwenhuijsen et al., 2000; Tardiff et al., 2006). Searches initially were conducted in December 2006 and January 2007. Based on the results of these searches, 24 chemicals were tentatively selected for MOA analysis: the four regulated trihalomethanes (bromodichloromethane, dibromochloromethane, bromoform, chloroform), nine haloacetic acids including the five regulated haloacetic acids (monochloro-, dichloro- and trichloroacetic acid; monobromoand dibromoacetic acid), four haloacetonitriles, a halopropanone (1,1,3,3-tetrachloropropanone), chlorine dioxide, and some other individual DBPs (chlorite, chloral hydrate, dichloromethane, bromomethane) (Table 1). Update searching on these selected chemicals has continued through July 2008 (we have updated some references that were in preparation at this time but are now published or accepted for publication, i.e., Lipscomb et al., 2009; Narotsky et al., 2011). The selection criteria included positive in vivo data from epidemiologic or experimental animal studies and/or MOA data for developmental effects. We also considered the availability of dose-response data, whole embryo culture data, and membership in the chemical classes (trihalomethanes and haloacetic acids) discussed in the U.S. EPA's (2006) primary drinking water regulations, if there was evidence of developmental toxicity in other members of the class.

In evaluating the data for adverse developmental outcomes, we considered established criteria for evidence of causality (Hill, 1965; U.S. EPA, 2005) and guidelines for adequacy of study design and statistical analysis in developmental toxicity studies (OECD, Organisation for Economic Co-operation and Development, 2001; U.S. EPA, 1991, 1998; U.S. FDA, U.S. Food and Drug Administration, 2000). The potential MOAs for developmental effects were evaluated according to published frameworks (Faustman et al., 2006; IPCS, International Programme on Chemical Safety, 2005; Meek et al., 2003; Seed et al., 2005; Sonich-Mullin et al., 2001; U.S. EPA, 2005). The evaluation of MOA includes identification of the potential key events, the temporal association of key events with the outcome (i.e., key events precede outcome), dose-response concordance between key events and the outcome, requirement of key events for the outcome to be expressed, consistency across studies, specificity of the association, biological plausibility and coherence, and relevance to humans.

\section{Results and discussion}

Results for the four outcomes of concern generally are discussed in the following order: the epidemiology data are reviewed first, the MOA data for that outcome (if available) are reviewed second and then supporting data are reviewed third.

\section{Spontaneous abortion/full-litter resorption}

A concern for spontaneous abortion arose because epidemiologic studies of drinking water DBPs associated this outcome with exposure to the trihalomethanes, and particularly exposure to bromodichloromethane (one of the four trihalomethanes regulated in drinking 
Table 1

Selected and non-selected disinfection byproducts.

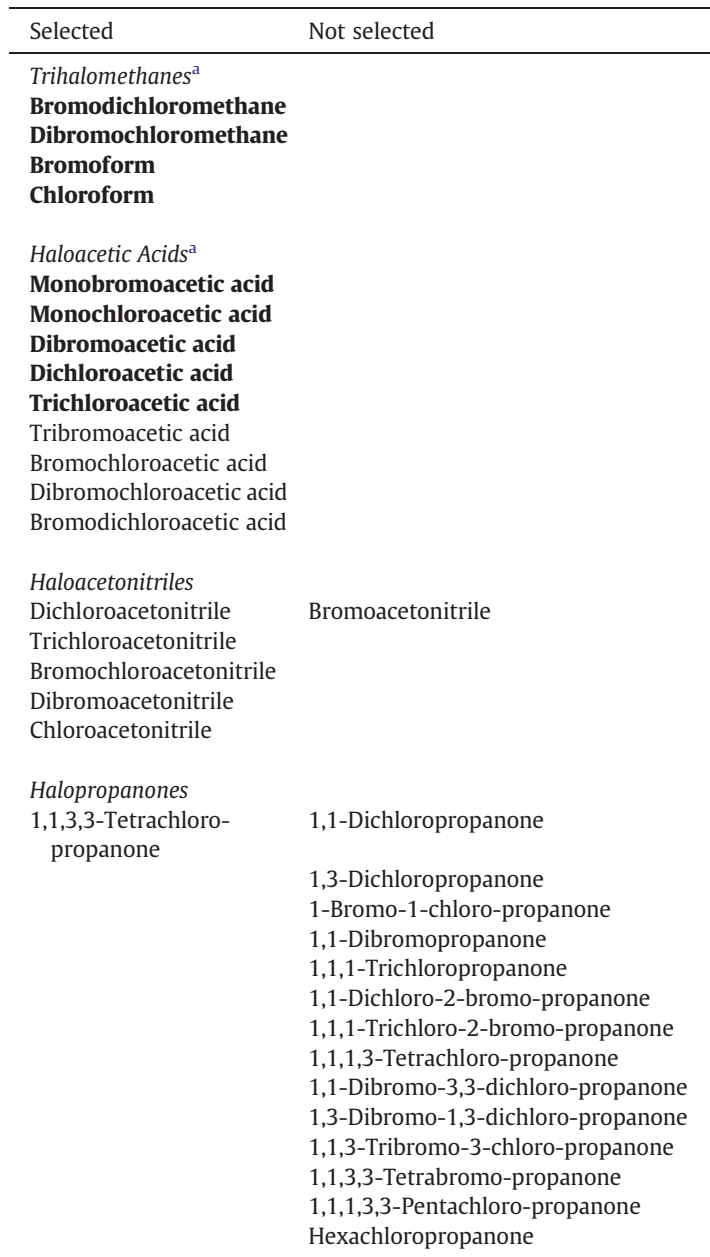

Other chemicals

Chlorine dioxide

Chlorite

Chloral hydrate

Dichloromethane

Bromomethane

a The trihalomethanes and haloacetic acids that are regulated in drinking water (U.S. EPA, 2006) are shown in boldface type.

water). Savitz et al. (1995), in a case-control study in North Carolina, reported an increased risk (odds ratio $[\mathrm{OR}]=2.8,95 \%$ confidence interval $[\mathrm{CI}]=1.1-2.7$ ) in the highest sextile of total trihalomethane concentration in drinking water, but the next lower sextile had an anomalously low risk. Swan et al. (1998) examined risk of spontaneous abortion among women enrolled at $\leq 13$ weeks of gestation in a prospective cohort study in Northern California. The authors reported an association $(\mathrm{OR}=2.2 ; 95 \% \mathrm{CI}=1.2-3.9)$ between spontaneous abortion and consumption of six or more glasses of cold treated tap water per day compared with those who drank no cold tap water. Following further analysis of the data to include bottled water consumption, they reported that the OR for spontaneous abortion in women who consumed at least six glasses of cold, treated tap water per day and no bottled water was $4.6(95 \% \mathrm{CI}=2.0-10.6)$ compared with those who drank at least six glasses of bottled water and no cold tap water. This effect, however, was observed in only one of the three geographic regions studied in California.

Waller et al. (1998) further evaluated the exposures in this study population with regard to consumption of total trihalomethanes and individual trihalomethanes in tap water. For all three regions combined, the consumption of at least five glasses of cold tap water containing at least $75 \mu \mathrm{g} / \mathrm{L}$ of total trihalomethanes was associated with spontaneous abortion $(\mathrm{OR}=1.8 ; 95 \% \mathrm{CI}=1.1-3.0)$. Bromodichloromethane was the only trihalomethane associated with spontaneous abortion in each region separately and all three regions combined. The OR among subjects from all study regions combined for consumption of at least five glasses of cold tap water containing at least $18 \mu \mathrm{g} / \mathrm{L}$ of bromodichloromethane was $2.0(95 \% \mathrm{CI}=1.2-3.5)$ and after adjustment for the other trihalomethanes was $3.0(95 \%$ $\mathrm{CI}=1.4-6.6)$.

Savitz et al. (2005, 2006) conducted an extensive prospective study of DBPs (including total and individual trihalomethanes) and pregnancy outcome in women planning pregnancy or who had completed less than 12 weeks of gestation in three southern cities in the U.S. Results for spontaneous abortion, analyzed so as to be consistent with the analysis of Waller et al. (1998), did not show an increased risk with daily consumption of at least five glasses of cold tap water containing $\geq 75 \mu \mathrm{g} / \mathrm{L}$ of total trihalomethanes (OR $=1.1$; $95 \% \mathrm{Cl}=0.7-1.7$ ). However, Savitz et al. (2005) did observe an increased risk of spontaneous abortion when expectant mothers consumed at least five glasses of cold tap water containing $\geq 18 \mu \mathrm{g} / \mathrm{L}$ per day of bromodichloromethane ( $\mathrm{OR}=1.58$; $95 \% \mathrm{Cl}=1.02-2.47$ ) (not adjusted for the other trihalomethanes). Using the upper quartile of bromodichloromethane concentration from their own study and consumption of at least five glasses of cold tap water, the result was virtually the same (OR $=1.6,95 \% \mathrm{CI}=1.0-2.4$ ) (Savitz et al., 2005, 2006). Despite largely null results from the Savitz et al. $(2005,2006)$ study (further discussed in the following paragraph), the results for bromodichlormethane provide some evidence of an association with increased incidence of spontaneous abortion in both the Waller et al. (1998) and the Savitz et al. (2005,2006) studies.

Savitz et al. (2005, 2006) also investigated potential associations between other exposure indices for total trihalomethane or bromodichloromethane and spontaneous abortion; results were largely null. The other indices included concentration in the drinking water, ingested amount from drinking water, showering/bathing exposure, and total integrated exposure. Savitz et al. $(2005,2006)$ reported an association between the highest quintile for ingested amount of total organic halide and spontaneous abortion $(\mathrm{OR}=1.5,95 \% \mathrm{CI}=1.0-2.2)$. As summarized in Table 2, the previously cited and a few other epidemiologic studies largely reported null results for an association between spontaneous abortion and exposure to most individual trihalomethanes or to total haloacetic acids. Thus, although the epidemiologic results raise a concern for spontaneous abortion, the weight of evidence for this outcome as a result of DBP exposure is weak and does not include information regarding a possible MOA.

Studies in experimental animals and in human tissue in vitro provide insights into a potential MOA for this effect. Narotsky and Laffan (2004) have suggested that full-litter resorption (pregnancy loss) in F344 rats could serve as a model for spontaneous abortion in humans. A number of individual DBPs cause full-litter resorption in rats, as indicated in Table 2. Although some of the studies summarized in Table 2 show this effect in the presence of marked maternal and embryo/fetal toxicity, studies of the trihalomethanes in sensitive strains of rats (F344 and Wistar) have demonstrated this effect in the absence of such toxicities and are discussed below as more relevant to concerns for human health.

Bromodichloromethane has been the DBP most extensively examined for pregnancy loss and its MOA for full-litter resorption in animals is reasonably well characterized. Evidence for the MOA of bromodichloromethane-induced pregnancy loss is as follows: gavage administration of bromodichloromethane to F344 rats during a portion of the luteinizing hormone (LH)-dependent period of pregnancy, which occurs during gestation days (GD) 7-10 resulted in full-litter resorption (Bielmeier et al., 2001, 2004; Narotsky et al., 1992, 1997a). The incidences of resorption were dose-related. A single 
Table 2

Summary of data on spontaneous abortion and full-litter resorption for selected disinfection byproducts (DBPs).

\begin{tabular}{|c|c|c|c|}
\hline DBP exposure measure & In vivo positive studies & In vivo negative studies & MOA data \\
\hline Chlorinated DW & Human, DW, epi (Swan et al., 1998) & - & - \\
\hline Total trihalomethanes (THMs) & $\begin{array}{l}\text { Human, DW, epi (Savitz et al., 1995) } \\
\text { Human, DW, epi (Waller et al., 1998) } \\
\text { F344 rat, G-aqueous emulphor (Alkamuls) } \\
\text { (Narotsky et al., 2011) }\end{array}$ & $\begin{array}{l}\text { Human, DW, epi (Savitz et al., 2005, 2006) } \\
\text { Human, DW, epi, time to pregnancy as } \\
\text { indicator of possible early pregnancy loss } \\
\text { (MacLehose et al., 2008)-also negative } \\
\text { for Brominated THM }\end{array}$ & - \\
\hline $\begin{array}{l}\text { Bromodichloromethane } \\
\quad \text { (BDCM) }\end{array}$ & $\begin{array}{l}\text { Human, DW, epi (Waller et al., 1998) } \\
\text { Human, DW, epi (Savitz et al., 2005, 2006) } \\
\text { F344 rat, G-aqueous emulphor (Bielmeier et al., } \\
\text { 2001, 2004) } \\
\text { F344 rat, G-aqueous emulphor-slight but not } \\
\text { significant increase (Narotsky et al., 1997a) } \\
\text { F344 rat, G-corn oil (Narotsky et al., 1997a) } \\
\text { F344 rat, G-corn oil (Narotsky et al., 1992) }\end{array}$ & $\begin{array}{l}\text { Human, DW, epi, time to pregnancy as } \\
\text { indicator of possible early pregnancy loss } \\
\text { (MacLehose et al., 2008) } \\
\text { SD rat G-aqueous emulphor (Bielmeier } \\
\text { et al., 2001, 2002) } \\
\text { SD rat, DW (Christian et al., 2001a) } \\
\text { SD rat, rabbit, DW, fertility not affected } \\
\text { (Christian et al., 2002a) } \\
\text { SD rat, DW (NTP, National Toxicology } \\
\text { Program, 1998a) }\end{array}$ & $\begin{array}{l}\text { In the rat, BDCM decreases serum LH, resulting } \\
\text { in decreased serum progesterone; F344 has less } \\
\text { constitutive LH than SD, LH in rats is analogous } \\
\text { to hCG in humans; hCG or progesterone } \\
\text { prevented full-litter resorption in rats treated } \\
\text { with BDCM (Narotsky and Laffan, 2004; } \\
\text { Bielmeier et al., 2001, 2002, 2004, 2007) } \\
\text { BDCM inhibited hCG-stimulated progesterone } \\
\text { secretion by rat corpora lutea in vitro (Bielmeier } \\
\text { et al., 2007) } \\
\text { BDCM inhibited differentiation of cultured } \\
\text { human placental trophoblast cells and } \\
\text { decreased hCG secretion and intracellular hCG } \\
\text { (Chen et al., 2003, 2004) } \\
\text { Rabbit, DW, limited data suggest BDCM } \\
\text { reaches placenta and fetus (Christian et al., } \\
\text { 2001b) } \\
\text { Generally, toxicity may be mediated through } \\
\text { metabolism to reactive and toxic intermediates } \\
\text { (ILSI, 1999) }\end{array}$ \\
\hline Dibromochloromethane & ]$^{-3}$ & $\begin{array}{l}\text { Human, DW, epi (Savitz et al., 2005, 2006) } \\
\text { Human, DW, epi (Waller et al., 1998) } \\
\text { SD rat, DW (NTP, National Toxicology } \\
\text { Program, 1996) }\end{array}$ & $\begin{array}{l}\text { Generally, toxicity may be mediated through } \\
\text { metabolism to reactive and toxic intermediates } \\
\text { (ATSDR, 2003; ILSI, 1999) }\end{array}$ \\
\hline Bromoform & $\begin{array}{l}\text { F344 rat, G-corn oil, developmental toxicity } \\
\text { screen (Narotsky et al., 1992, } 1993\end{array}$ & $\begin{array}{l}\text { Human, DW, epi (Waller et al., 1998) } \\
\text { Human, DW, epi (Savitz et al., 2005, 2006) } \\
\text { SD rat, G (Ruddick et al., 1983) }\end{array}$ & $\begin{array}{l}\text { Generally, toxicity may be mediated through } \\
\text { metabolism to reactive and toxic intermediates } \\
\text { (ATSDR, 2003; ILSI, 1999) }\end{array}$ \\
\hline Chloroform & $\begin{array}{l}\text { Wistar Rat, Inhal. (Baeder and Hoffmann, 1988) } \\
\text { Also suggestive data: } \\
\text { SD rat, Inhal., low pregnancy rate( } 3 / 20 \text {, } \\
\text { including one fully resorbed; uteri not stained, } \\
\text { so uncertain if full-litter resorption occurred in } \\
\text { "nonpregnant" rats), severe maternal weight } \\
\text { loss, fetotoxicity in the } 2 \text { surviving litters } \\
\text { (Schwetz et al., 1974) } \\
\text { CF-1 mouse, Inhal., low pregnancy rates, not } \\
\text { accounted for by stain-detected resorptions: } \\
\text { (possible very early resorption or interference } \\
\text { with implantation), maternal liver toxicity } \\
\text { (Murray et al., 1979) }\end{array}$ & $\begin{array}{l}\text { Human, DW, epi (Waller et al., 1998) } \\
\text { Human, DW, epi (Savitz et al., 2005, 2006) } \\
\text { SD rat, G-corn oil, fertility not affected } \\
\text { (Thompson et al., 1974) }\end{array}$ & $\begin{array}{l}\text { At end of single 4-hour inhalation exposure on } \\
\text { GD 17, fetal to maternal chloroform } \\
\text { concentration ratio was 0.316; fetal } \\
\text { concentration was not related to position in } \\
\text { uterus (Withey and Karpinski, 1985) } \\
\text { Generally, toxicity may be mediated } \\
\text { through metabolism to reactive and } \\
\text { toxic intermediates (ILSI, 1999; U.S. EPA, 2001) }\end{array}$ \\
\hline $\begin{array}{l}\text { Total trihalomethanes and } \\
\text { total haloacetic acid } \\
\text { mixture }(50: 50 \% \text {, molar } \\
\text { basis) }\end{array}$ & $\begin{array}{l}\text { Suggestive data: } \\
\text { F344 rat, G-aqueous emulphor (Alkamuls) } \\
\text { (Narotsky et al., 2011) }\end{array}$ & $\mathrm{C}$ & $\begin{array}{l}\text { Pregnancy loss seen at lower doses of THMs and } \\
\text { HAAs than when either was tested separately, } \\
\text { but data were not adequate to determine mode } \\
\text { of joint toxic action (Narotsky et al., 2011) }\end{array}$ \\
\hline $\begin{array}{l}\text { Total haloacetic acids } \\
\text { (HAAs) }\end{array}$ & $\begin{array}{l}\text { Suggestive data: } \\
\text { F344 rat, G-aqueous emulphor (Alkamuls) } \\
\text { (Narotsky et al., 2011) }\end{array}$ & $\begin{array}{l}\text { Human, DW, epi (Savitz et al., 2005, 2006) } \\
\text { Human, DW, epi, time to pregnancy as } \\
\text { indicator of possible early pregnancy loss } \\
\text { (MacLehose et al., 2008) - also negative } \\
\text { for brominated HAAs }\end{array}$ & $e^{3}$ \\
\hline Monobromoacetic acid & - & LE rat, G-water (Randall et al., 1991) & - \\
\hline Monochloroacetic acid & - & $\begin{array}{l}\text { LE rat-G-water (Smith et al., 1990) } \\
\text { SD rat-DW (Johnson et al., 1998) }\end{array}$ & 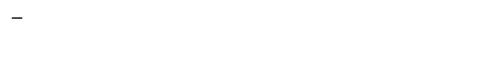 \\
\hline Dibromoacetic acid (DBA) & - & $\begin{array}{l}\text { SD rat-G-water, also serum LH not } \\
\text { affected but assay insensitive, serum } \\
\text { progesterone not affected, serum estradiol } \\
\text { increased (Cummings and Hedge, 1998) } \\
\text { SD rat, DW, fertility not affected (Christian } \\
\text { et al., 2002b) }\end{array}$ & $\begin{array}{l}\text { SD rat, DW, parent compound reaches placenta, } \\
\text { amniotic fluid and fetus (Christian et al., } \\
\text { 2001b); was dose additive with BCA and/or DCA } \\
\text { on development of rat embryo in culture } \\
\text { (Andrews et al., 2004) } \\
\text { Inhibited neural crest cell migration } \\
\text { in cultured explants from rats and } \\
\text { mice (Andrews et al., 2001; Hunter et al., 2001) } \\
\text { Did not induce apoptosis in mouse embryo } \\
\text { culture (Ward et al., 2000) } \\
\text { Is more potent than its metabolites in mouse } \\
\text { embryo culture (Hunter and Rogers, 1999) }\end{array}$ \\
\hline Dichloroacetic acid (DCA) & - & $\begin{array}{l}\text { LE rat-G-water (Smith et al., 1992a) } \\
\text { SD rat, G-water (Fisher et al., 2001) }\end{array}$ & $\begin{array}{l}\text { LE rat, G, antagonistic interaction for resorption } \\
\text { with TCA (Smith et al., 1991, 1992b) } \\
\text { Was dose additive with DBA and/or BCA on } \\
\text { development of rat embryo in culture (Andrews } \\
\text { et al., 2004) }\end{array}$ \\
\hline
\end{tabular}


Table 2 (continued)

\begin{tabular}{|c|c|c|c|}
\hline DBP exposure measure & In vivo positive studies & In vivo negative studies & MOA data \\
\hline Dichloroacetic acid (DCA) & & & $\begin{array}{l}\text { LE rat, G, at } 48 \text { hours after dosing of dams with } \\
\text { 1- and } 2-\left({ }^{14} \mathrm{C}\right) \text {-labeled DCA, }{ }^{14} \text { C levels were } \\
\text { higher in embryos than in maternal plasma, and } \\
\text { were present mainly as C2 (the dichloromethyl } \\
\text { C), indicating a metabolite (Roth et al., 1991) } \\
\text { DCA has multiple effects in intermediary } \\
\text { metabolism, particularly from inhibition of the } \\
\text { kinase that inactivates mitochondrial pyruvate } \\
\text { dehydrogenase (Crabb et al., 1981; Smith et al., } \\
\text { 1992a; Stacpoole, 1989) } \\
\text { DCA induces apoptosis in mouse embryos } \\
\text { (Ward et al., 2000) } \\
\text { DCA did not inhibit neural crest cell migration in } \\
\text { culture (Andrews et al., 2001; Hunter et al., } \\
\text { 2001) } \\
\text { Has similar potency to its metabolites in mouse } \\
\text { embryo culture (Hunter and Rogers, 1999) }\end{array}$ \\
\hline Bromochloroacetic acid (BCA) & - & $\begin{array}{l}\text { SD rat, DW (but decrease in implants and } \\
\text { live fetuses per litter at maternotoxic } \\
\text { dose) (NTP, National Toxicology Program, } \\
\text { 1998b) }\end{array}$ & $\begin{array}{l}\text { Was dose additive with DBA and/or DCA on } \\
\text { development of rat embryo in culture (Andrews } \\
\text { et al., 2004) } \\
\text { Inhibited neural crest cell migration in cultured } \\
\text { explants from rats and mice (Andrews et al., } \\
\text { 2001; Hunter et al., 2001) } \\
\text { Induces apoptosis in mouse embryos (Ward } \\
\text { et al., 2000) } \\
\text { Metabolites of BCA were much less potent than } \\
\text { BCA in mouse embryo culture (Hunter and } \\
\text { Rogers, 1999) } \\
\text { BCA caused differential gene expression in } \\
\text { mouse embryo culture (Karoly et al., 2004) }\end{array}$ \\
\hline Tribromoacetic acid & 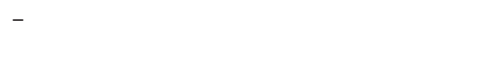 & $\begin{array}{l}\text { SD rat, DW (NTP, National Toxicology } \\
\text { Program, 1998c) }\end{array}$ & 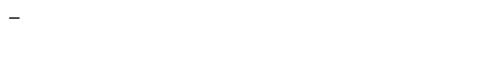 \\
\hline Trichloroacetic acid (TCA) & $\begin{array}{l}\text { LE rat, G-water, also maternal toxicity and fetal } \\
\text { toxicity and malformations (Smith et al., 1989a) }\end{array}$ & SD rat, G-water (Fisher et al., 2001) & $\begin{array}{l}\text { LE rat, G, antagonistic interaction with DCA on } \\
\text { resorption (Smith et al., 1991, 1992b) }\end{array}$ \\
\hline Dibromochloroacetic acid & - & $\begin{array}{l}\text { SD rat-DW (NTP, National Toxicology } \\
\text { Program, 2000) }\end{array}$ & - \\
\hline Bromodichloroacetic acid & - & - & - \\
\hline Dichloroacetonitrile & $\begin{array}{l}\text { LE rat, G-tricap, screen one dose, with replicate, } \\
\text { GD7-15, also maternal and fetal toxicity (Smith } \\
\text { et al., 1987) }\end{array}$ & - & $\begin{array}{l}\text { Metabolism to cyanide does not appear to } \\
\text { account for developmental toxicity (Christ et al., } \\
\text { 1995; Smith et al., 1988) }\end{array}$ \\
\hline
\end{tabular}

LE rat, G-tricap, also maternal mortality (nonsignificant), fetal toxicity and malformations

(Smith et al., 1989b)

Suggestive data:

LE rat, G-tricap, screen one dose, GD7-15, 45\% of sperm-positive rats not pregnant (possibly due to late preimplantation loss or very early resorptions) in 1 of 2 replicate dose groups (Smith et al., 1987)

Trichloroacetonitrile (TCAN) LE rat, G-tricap, also with maternal and fetal toxicity and malformations at higher doses (Smith et al., 1988)

LE rat, G-corn oil (Christ et al., 1996)

LE rat, G-tricap, screen one dose, GD7-15 (Smith et al., 1987)

Suggestive data:

LE rat, G-tricap, replicate screen one dose, GD7$15,45 \%$ of sperm positive rats not pregnant (possibly due to late preimplantation loss or very early resorption) (Smith et al., 1987)

Bromochloro-acetonitrile LE rat, G-tricap, also maternal mortality and fetal toxicity and malformations (Christ et al., 1995)

Dibromoacetonitrile

Chloroacetonitrile

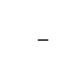

1,1,3,3,-Tetrachloropropanone

Chlorine dioxide

SD rat, DW (but decrease in implants and tuses per litter at maternotoxic 1998b)

SD rat, DW (NTP, National Toxicology Program, 1998c)

SD rat-DW (NTP, National Toxicology Program, 2000) 1995; Smith et al., 1988)

Metabolism to cyanide does not appear to account for developmental toxicity (Christ et al., 1995; Smith et al., 1988)

LE rat, $\mathrm{G}$, accumulation of radioactivity in maternal liver and in fetus from two to three daily doses of ${ }^{14} \mathrm{C}$-TCAN was higher for the trichloromethyl carbon (C2) than the cyano carbon. Accumulation in embryos was higher with tricaprylin vehicle than corn oil vehicle (Gordon et al., 1991)

LE rat, G-tricap, screen one dose, GD7-15 Metabolism to cyanide does not appear to (Smith et al., 1987) account for developmental toxicity (Christ et al. 1995; Smith et al., 1988)

LE rat, G-tricap, screen one dose, GD7-15 (Smith et al., 1987)

SD rat, DW (NTP, National Toxicology Program, 1997)

LE rat, G-tricap, screen one dose, GD7-15 (Smith et al., 1987)

CF-1 mouse, rabbit, G-corn oil, fertility not affected (John et al., 1982)

Rat, SD, DW, but small group sizes (Suh et al., 1983)

Rat, LE, but highest dose not MTD (Carlton et al., 1991)
Metabolism to cyanide does not appear to account for developmental toxicity (Christ et al., 1995; Smith et al., 1988)

Metabolism to cyanide does not appear to account for developmental toxicity (Christ et al. 1995; Smith et al., 1988)

Generally, toxicity is considered due to oxidative properties (U.S. EPA, 2000b)

Decreased the levels of circulating thyroxine in monkeys and rats, and in developmental study 
Table 2 (continued)

\begin{tabular}{|c|c|c|c|}
\hline DBP exposure measure & In vivo positive studies & In vivo negative studies & MOA data \\
\hline Chlorine dioxide & & & $\begin{array}{l}\text { in rats, possibility through oxidation of dietary } \\
\text { iodide in the GI tract, resulting in reactive } \\
\text { species that iodinate organic matter to form } \\
\text { potentially thyroid inhibitory compounds } \\
\text { (Bercz et al., 1986; Orme et al., 1985) }\end{array}$ \\
\hline Chlorite & $\begin{array}{l}\text { SD rat, DW, GD7-14, also maternal toxicity } \\
\text { (body weight loss and hemolysis) and greatly } \\
\text { decreased water and food intake; only } 5 \text { rats/ } \\
\text { group (Couri et al., 1982) } \\
\text { Suggestive data: } \\
\text { A/J mouse, DW, fertility decreased (Moore et al., } \\
\text { 1980) }\end{array}$ & $\begin{array}{l}\text { SD rat, DW, fertility not affected (Gill et al., } \\
\text { 2000) } \\
\text { LE Rat, DW, fertility not affected (Carlton } \\
\text { and Smith, 1985, Carlton et al., 1987) } \\
\text { Rabbit, DW, fertility not affected } \\
\text { (Harrington et al., 1995) }\end{array}$ & $\begin{array}{l}\text { Generally, toxicity is considered due to } \\
\text { oxidative properties (U.S. EPA, 2000b) }\end{array}$ \\
\hline Chloral hydrate & - & $\begin{array}{l}\text { SD rat, DW, but MTD not achieved } \\
\text { (Johnson et al., 1998) }\end{array}$ & $\begin{array}{l}\text { The metabolite trichloroethanol has } \\
\text { sedative effects. Other metabolites are } \\
\text { trichloroacetic acid and possibly small } \\
\text { amounts of dichloroacetic acid (U.S. EPA, } \\
\text { 2000a). }\end{array}$ \\
\hline Dichloromethane & - & $\begin{array}{l}\text { F344 Rat, G-corn oil (Narotsky and } \\
\text { Kavlock, 1995) } \\
\text { F344 rat, Inhal., fertility unaffected but } \\
\text { highest exposure not MTD (Nitschke et al., } \\
\text { 1988) } \\
\text { SD rat, G-water, MTD not achieved, small } \\
\text { number animals/group (IRDC, } \\
\text { International Research and Development } \\
\text { Corporation, 1976) }\end{array}$ & $\begin{array}{l}\text { Generally, toxicity may be due to P450 } \\
\text { metabolism to a reactive intermediate and } \\
\text { carbon monoxide, and to direct conjugation of } \\
\text { dichloromethane with GSH to form a bioactive } \\
\text { product. Also, the parent } \\
\text { compound may enter cell membranes } \\
\text { and thereby interfere with signal transmission } \\
\text { (ATSDR, 2000). }\end{array}$ \\
\hline Bromomethane & $\begin{array}{l}\text { RIV-TOX rat, also severe maternal toxicity } \\
\text { including perforated stomach, peritonitis, and } \\
\text { mortality (Peters et al., 1981) }\end{array}$ & $\begin{array}{l}\text { Rabbit, Inhal. (Breslin et al., 1990) } \\
\text { Wistar rat, rabbit, Inhal., fertility not } \\
\text { affected but MTD not achieved (Sikov } \\
\text { et al., 1981) }\end{array}$ & $\begin{array}{l}\text { Generally, toxicity may be due to the alkylating } \\
\text { (methylating) properties of bromomethane } \\
\text { (ATSDR, 1992; Vogel and Nivard, 1994). }\end{array}$ \\
\hline
\end{tabular}

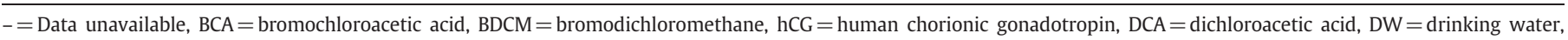

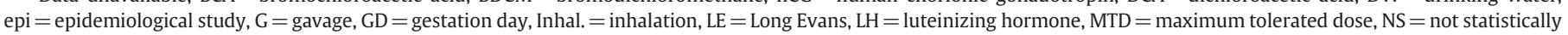
significant, $\mathrm{SD}=$ Sprague-Dawley, TCA = trichloroacetic acid, TCAN = trichloroacetonitrile, tricap $=$ tricaprylin.

a Animals were exposed on at least days 6-15 of gestation unless noted otherwise (where GD0 = sperm-positive or vaginal plug; GDs or embryo age adjusted to this basis). Tested at doses/exposures that included an MTD unless otherwise noted.

dose on GD 8 or 9 or repeated daily dosing on GD 6-10 or 6-15 caused the effect, whereas daily dosing on GD 11-15 did not, indicating that the effect may not occur outside a specific temporal window. In surviving litters, no changes in gestation length, no increases in malformations or resorptions, and no effects on fetal or pup weights were observed. Thus, the effect was an all-or-nothing phenomenon.

During GD 7-10 in the rat, the corpora lutea, which secrete progesterone, are dependent on LH, secreted by the pituitary, to stimulate progesterone release. The key events in the rat that led to full-litter resorption from bromodichloromethane exposure were (1) exposures to bromodichloromethane during the LH-dependent period, which resulted in (2) a decrease in serum LH, which resulted in (3) a decrease in progesterone. Bielmeier et al. (2001, 2004) observed these key events in F344 dams whose litters were fully resorbed in response to bromodichloromethane. Full-litter resorption did not occur in Sprague-Dawley rats tested at the same dose levels that caused full-litter resorption in F344 rats in the same study. Signs of maternal toxicity, including decreased body weight gain, occurred in both strains/stocks of rat in these studies, indicating that the maximum tolerated dose (MTD) was achieved.

In an intra-study comparison of the F344 and the Sprague-Dawley rats, oral bromodichloromethane decreased the serum LH levels in Sprague-Dawley rats as well as in F344 rats (Bielmeier et al., 2002). The Sprague-Dawley rats, however, had much higher constitutive levels of LH, such that even when decreased in response to bromodichloromethane exposure, their LH values were higher than in control F344 rats. Following oral bromodichloromethane exposure, the F344 rats experienced decreased serum progesterone; in contrast, the Sprague-Dawley rats did not. The comparisons between these strains/stocks indicate that a decrease in LH beyond a critical level appears to be a necessary key step resulting in decreased serum progesterone and that the decreased serum progesterone is a necessary key step for the occurrence of full-litter resorption in response to bromodichloromethane treatment. This difference across strains/stocks may explain why full-litter resorption was not seen in studies of bromodichloromethane in Sprague-Dawley rats (summarized in Table 2), including in the drinking water study by Christian et al. (2001a). In vitro, bromodichloromethane inhibited human chorionic gonadotropin (hCG)-stimulated progesterone secretion by rat corpora lutea, suggesting that bromodichloromethane may also affect corpora lutea responsiveness (Bielmeier et al., 2007).

Sampling for serum hormone analysis at 2- to 4-hour intervals after dosing of F344 rats with bromodichloromethane on GD 9 revealed that a decrease in serum $\mathrm{LH}$ occurred prior to the decrease in progesterone (Bielmeier et al., 2004), establishing the temporal sequence. The administration of either progesterone or the $\mathrm{LH}$ agonist, hCG, prevented full-litter resorption. These results provide further evidence that the key steps outlined in Fig. 1 are necessary for the effect. The results further suggest that bromodichloromethane may have altered LH secretion and that the consequent decreased progesterone was a key step leading to full-litter resorption.

In the pregnant rat, the pituitary gland secretes LH in response to gonadotropin-releasing-hormone $(\mathrm{GnRH})$ stimulation from the hypothalamus. In the pregnant human, the placental trophoblast both secretes GnRH and expresses a receptor for this hormone. GnRH secreted by the cytotrophoblast stimulates the placental syncytiotrophoblast to secrete hCG, which in turn stimulates corpora luteal secretion of progesterone. Thus, both LH secretion in the rat and hCG secretion in the human are regulated by GnRH (as reviewed by Bielmeier et al., 2004; Chen et al., 2003, 2004). Fig. 2 provides a comparison of the rat and human hormonal maintenance of the 
corpora lutea, essential for progesterone secretion and ultimately embryo survival.

Chen et al. (2003) conducted in vitro studies with cultures of human placental syncytiotrophoblasts and found that bromodichloromethane, at concentrations higher than found in human blood, decreased the secretion of hCG from these differentiated cells without affecting morphology or viability of the cells. Subsequently, Chen et al. (2004) reported that incubation of bromodichloromethane with undifferentiated human placental trophoblast cells inhibited hCG secretion at a bromodichloromethane concentration of $0.5 \mathrm{nM}$ $(0.082 \mu \mathrm{g} / \mathrm{L})$, which is within the range found in human blood $(0.002-0.093 \mu \mathrm{g} / \mathrm{L}$, Miles et al., 2002). At higher concentrations, bromodichloromethane decreased the intracellular levels of hCG and inhibited differentiation of the trophoblasts to syncytiotrophoblast colonies. Thus, although the entire sequence of key events is not yet completely known, existing data suggest that the MOA of bromodichloromethane in the F344 rat may be qualitatively similar to that in the human and may be operative at blood levels relevant to human exposure (thus quantitatively plausible). Therefore, the developmental effects observed in the F344 rat in response to bromodichloromethane are considered relevant to humans. In addition, epidemiologic studies, described previously, report an association between exposure to the total trihalomethanes and to bromodichloroemethane in drinking water and spontaneous abortion in humans (Savitz et al., 2005, 2006; Waller et al., 1998).

Bromoform, chloroform, and a trihalomethane mixture also induced full-litter resorption in rats. Bromoform caused full-litter resorption in F344 rats treated daily by gavage on GD 6-15 (Narotsky et al., 1992, 1993). Incidences of full-litter resorption were doserelated (M. Narotsky, unpublished results). Resorption rates were not affected in the surviving litters (Narotsky et al., 1993); i.e., this was an all-or-nothing effect, similar to that seen with bromodichloromethane. Chloroform caused full-litter resorption in Wistar rats exposed by inhalation for 7 hours/day on GD 6-15 (normalized to sperm-positive $=$ GD 0 ) to concentrations of chloroform that affected maternal body weights (Baeder and Hoffmann, 1988). A doseresponse relationship was observed, and no effects on resorption or incidences of malformations were seen in surviving litters. These results in Wistar rats exposed to chloroform by inhalation are similar to those obtained with F344 rats treated with bromodichloromethane or bromoform by gavage as described above. Additional data suggestive of an effect of chloroform on pregnant rats (see Murray et al., 1979; Schwetz et al., 1974) are listed in Table 2. A trihalomethane mixture, using proportions similar to those found in some chlorinated tap waters, caused pregnancy loss in a dose-related manner in F344 rats following gavage administration on GD 6-20 (Narotsky et al., 2011).

While the remaining trihalomethane of interest, dibromochloromethane, did not cause developmental effects in Sprague-Dawley rats (NTP, National Toxicology Program, 1996), it has not been tested for developmental toxicity in the known sensitive strain of rat, F344, or for effects on LH or progesterone levels. Therefore, it is unclear whether dibromochloromethane would cause full-litter resorption, similar to its structural analogs. However, the non-DBP tetrahalomethane carbon tetrachloride, which is structurally related to the trihalomethanes, also causes full-litter resorption in the F344 rat (Narotsky and Kavlock, 1995; Narotsky et al., 1997a,b). Conversely, dichloromethane, a dihalomethane, did not cause full-litter resorption when tested similarly by gavage in F344 rats (Narotsky and Kavlock, 1995).

One of the nine selected haloacetic acids (eight were tested for this effect) and three of the five selected haloacetonitriles caused full-litter resorption in Long-Evans rats when administered daily by gavage on GD 6-15 or 7-15 (Table 2), but the pattern of effects was different than that seen with bromodichloromethane in the F344 rat. With bromodichloromethane, the effect appeared to be an all-or-nothing

\section{Bromodichloromethane Exposure Rat Pregnancy - Days 7-10 (LH-dependent period)}

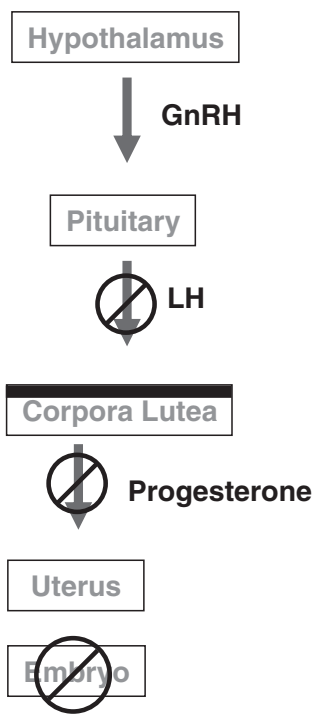

Fig. 1. Key steps in bromodichloromethane MOA for full-litter resorption.

phenomenon: litters were either fully resorbed or survived with no effects (i.e., no increase in resorptions per surviving litter and no fetal effects) (Bielmeier et al., 2001, 2004; Narotsky et al., 1992, 1997a). When the haloacetic acids and haloacetonitriles (trichloroacetic acid, dichloroacetonitrile, trichloroacetonitrile, bromochloroacetonitrile) were tested in Long-Evans rats, they caused full-litter resorption with a dose-related progression of increased (per litter) resorption, malformations, and fetal weight depression in surviving litters (Christ et al., 1995, 1996; Smith et al., 1987, 1988, 1989a,b). These findings suggest that the partial and full-litter resorptions from these chemicals may be due to direct effects on the embryo or fetus rather than disruption of hormonal maintenance of pregnancy in

\section{Luteal Maintenance}

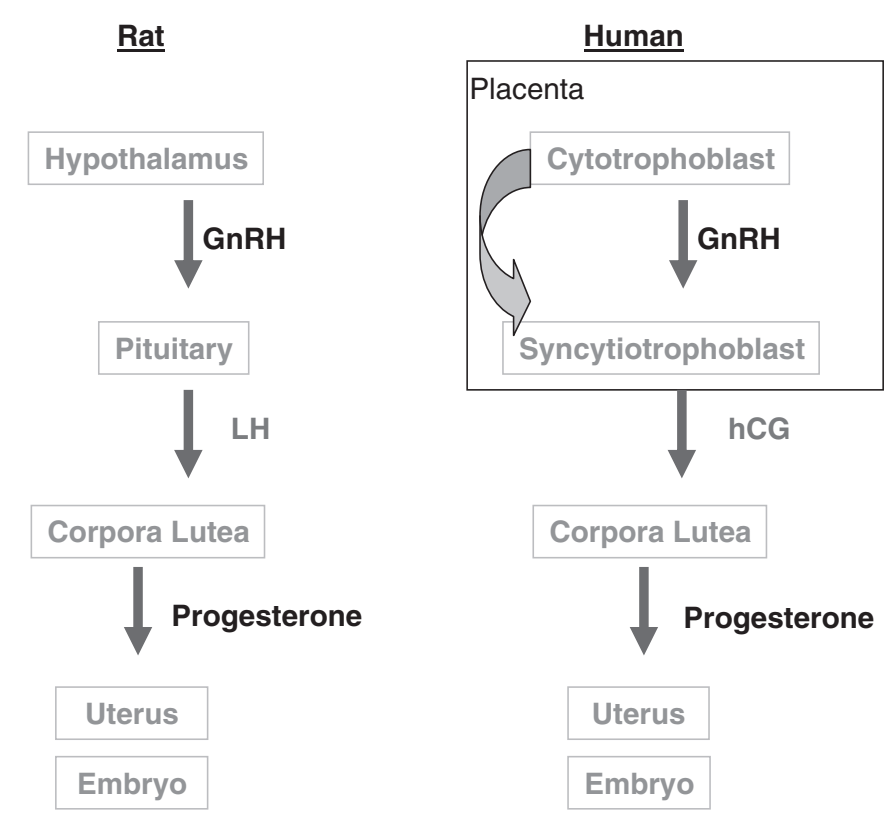

Fig. 2. Comparison of rat and human hormonal maintenance of corpora lutea. 
Table 3

Summary of data on cardiovascular malformations for selected disinfection byproducts (DBPs).

\begin{tabular}{|c|c|c|c|c|c|}
\hline DBP exposure measure & In vivo positive studies & In vivo negative studies & $\begin{array}{l}\text { Embryo culture } \\
\text { positive studies }\end{array}$ & $\begin{array}{l}\text { Embryo culture-negative } \\
\text { studies }\end{array}$ & MOA data \\
\hline Chlorinated DW & $\begin{array}{l}\text { Human, DW, epi (Hwang et al., } \\
\text { 2002) }\end{array}$ & $\begin{array}{l}\text { Human, DW, epi (Cedergren et } \\
\text { al., 2002) } \\
\text { Human, DW, epi (Kallen and } \\
\text { Robert, 2000) } \\
\text { Human, DW, epi (Magnus et } \\
\text { al., 1999) }\end{array}$ & - & - & - \\
\hline Total trihalomethanes & $\begin{array}{l}\text { Human, DW, epi (Chisholm et } \\
\text { al., 2008) } \\
\text { Human, DW, epi (Hwang et al., } \\
\text { 2008) } \\
\text { Human, DW, epi } \\
\text { (Nieuwenhuijsen et al., 2008) } \\
\text { Human, DW, epi (Cedergren } \\
\text { et al., 2002) } \\
\text { Suggestive data: } \\
\text { Human, DW also contaminated } \\
\text { with solvents, epi (Bove et al., } \\
\text { 1995) }\end{array}$ & $\begin{array}{l}\text { Human, DW, epi (Shaw et al., } \\
\text { 2003) } \\
\text { Human, DW, epi (Dodds et al., } \\
\text { 1999) }\end{array}$ & - & - & - \\
\hline $\begin{array}{l}\text { Bromodichloromethane } \\
\text { (BDCM) }\end{array}$ & - & $\begin{array}{l}\text { Human, DW, epi (Dodds and } \\
\text { King, 2001) } \\
\text { Human, DW, epi (Shaw et al., } \\
\text { 2003) } \\
\text { SD rat, G-corn oil (Ruddick et } \\
\text { al., 1983) } \\
\text { SD rat, rabbit, DW (Christian et } \\
\text { al., 2001a) }\end{array}$ & - & - & $\begin{array}{l}\text { Rabbit, DW, limited data suggest BDCM } \\
\text { reaches the placenta and fetus (Christian et } \\
\text { al., 2001b). } \\
\text { Generally, toxicity may be mediated through } \\
\text { metabolism to reactive and toxic } \\
\text { intermediates (ILSI, 1999). }\end{array}$ \\
\hline Dibromochloromethane & - & $\begin{array}{l}\text { Human, DW, epi (Shaw et al., } \\
\text { 2003) } \\
\text { SD rat, G-corn oil (Ruddick et } \\
\text { al., 1983) } \\
\text { ICR Swiss mouse, DW } \\
\text { (Borzelleca and Carchman, } \\
\text { 1982) }\end{array}$ & - & - & $\begin{array}{l}\text { Generally, toxicity may be mediated through } \\
\text { metabolism to reactive and toxic } \\
\text { intermediates (ATSDR, 2003; ILSI, 1999). }\end{array}$ \\
\hline Bromoform & $\begin{array}{l}\text { Human, DW, epi } \\
\text { (Nieuwenhuijsen et al., 2008) }\end{array}$ & $\begin{array}{l}\text { Human, DW, epi (Shaw et al., } \\
\text { 2003) } \\
\text { SD rat, G-corn oil (Ruddick et } \\
\text { al., 1983) }\end{array}$ & - & - & $\begin{array}{l}\text { Generally, toxicity may be mediated through } \\
\text { metabolism to reactive and toxic } \\
\text { intermediates (ATSDR, 2003; ILSI, 1999). }\end{array}$ \\
\hline Chloroform & - & $\begin{array}{l}\text { Human, DW, epi (Dodds and } \\
\text { King, 2001) } \\
\text { SD rat, G-corn oil (Ruddick et } \\
\text { al., 1983) } \\
\text { SD rat, rabbit, G-corn oil } \\
\text { (Thompson et al., 1974) } \\
\text { ICR Swiss mouse, DW, but only } \\
6 \text { litters/group (Borzelleca and } \\
\text { Carchman, 1982) } \\
\text { Wistar rat, Inhal. (Baeder and } \\
\text { Hoffmann, 1988, 1991a,b) } \\
\text { CF-1 mice, Inhal. (Murray et al, 1979) } \\
\text { SD rats, Inhal. (Schwetzet al., 1974) }\end{array}$ & - & $\begin{array}{l}\text { SD rat, day } 10.5 \text { ( } 12-15 \text { somites), diffuse } \\
\text { cell death (except in heart), including } \\
\text { neuroepithelium of neural tube, eye } \\
\text { defects, but effects may be due to loss of } \\
\text { yolk sac vascularization (Brown- } \\
\text { Woodman et al., 1998). }\end{array}$ & $\begin{array}{l}\text { At end of single 4-hour inhalation exposure } \\
\text { on GD 17, fetal to maternal chloroform } \\
\text { concentration ratio was 0.316; fetal } \\
\text { concentration was not related to position in } \\
\text { uterus (Withey and Karpinski, 1985). } \\
\text { Generally, toxicity may be mediated through } \\
\text { metabolism to reactive and toxic } \\
\text { intermediates (ILSI, 1999; U.S. EPA, 2001). }\end{array}$ \\
\hline
\end{tabular}


DBP exposure measure

In vivo positive studies

In vivo negative studies

Monobromoacetic acid

Suggestive data: (not litter-

based):

LE rat, G-water, aorta-ventricle

communication defect, also eye

defects (micro- and

anophthalmia) (Randall et al.,

1991)

Monochloroacetic acid

Sugges

sased):

LE rat, G-water, mainly

levocardia (Smith et al., 1990)

Dibromoacetic acid (DBA)

Dichloroacetic acid (DCA)

LE rat, G-water, primarily defect between aorta and ventricle, also levocardia; eye defects without clear dose-respons (Smith et al., 1992a)

LE rat, G-water, higher doses on

GD9-11 or $12-15$, mainly

interventricular septal defects

(Epstein et al., 1992)
SD rat, DW, MTD not achieved CD-1 mouse, day 8 (3-6 somites), also

(Johnson et al., 1998)

SD rat, G-water (Fisher et al., CD-1 mouse, day 8 (3-6 somites), also 2001)

from dibromoacetic acid in same study)

(Andrews et al., 2004)
Embryo culture

CD-1 mouse, day 8 (3-6 somites), also

neural tube, ${ }^{\mathrm{b}}$ pharyngeal arch and eye

defects (Hunter et al., 1996)

neural tube ${ }^{\mathrm{b}}$ and pharyngeal arch defects

(Hunter et al., 1996)

CD-1 mouse, day 8 (3-6 somites), also neural tube, ${ }^{\mathrm{b}}$ pharyngeal arch and eye defects (Hunter et al., 1996, 2006b) SD rat, day 9.5 (0-1 somites), also hypoplasia of prosencephalon and viscer arches and eye defects (Andrews et al. 2004)

studies neural tube, ${ }^{\mathrm{b}}$ pharyngeal arch and eye defects (Hunter et al., 1996, 2006b) Suggestive data:

SD rat day 9.5 ( $0-1$ somites) SD rat, day 10 (4-7 somites), hypoplasia of prosencephalon, eye defects,

defreased yolk sac diameter; neural tube poor survival at higher concentration

(Saillenfait et al., 1995)
SD rat, DW, parent compound reaches placenta, amniotic fluid and fetus (Christian et al., 2001b)

Was dose additive with BCA and/or DCA on development of rat embryo in culture (Andrews et al., 2004)

Inhibited neural crest cell migration in cultured explants from rat and mouse embryos (Andrews et al., 2001; Hunter et al., 2001)

Did not induce apoptosis in mouse embryo culture (Ward et al., 2000)

Is more potent than its metabolites in mouse embryo culture (Hunter and Rogers, 1999)

LE rat $G$, antagonistic interaction for malform a 1992b)

Was dose additive with DBA and/or BCA on (Aelopment of rat embryo in culture (Andrews et al., 2004)

LE rat, G, at 48 hours after dosing of dams with 1- and $2-\left({ }^{14} \mathrm{C}\right)$-labeled DCA, ${ }^{14} \mathrm{C}$ levels were higher in embryos than in maternal plasma, and were present mainly as C2 (the dichloromethyl C), indicating a metabolite (Roth et al., 1991).

DCA has multiple effects in intermediary metabolism, particularly from inhibition of the kinase that inactivates mitochondrial pyruvate dehydrogenase (Crabb et al., 1981; Smith et al., 1992a; Stacpoole, 1989).

DCA-induced malformations in cultured mouse embryos are not primarily due to reactive oxygen species (Hunter et al., 2006c).

DCA induces apoptosis in mouse embryos, including in the heart (Ward et al., 2000). DCA did not inhibit neural crest cell migration culture (Andrews et al., 2001; Hunter et al., 2001).

Has similar potency to its metabolites in mouse embryo culture (Hunter and Rogers, 1999) 

Program, 1998c)

Tribromoacetic acid

Trichloroacetic acid (TCA)

SD rat, DW, ventricular and atrial septal defects (Johnson et 2001)

al., 1998)

E rat, G-water, primarily levocardia, also IV septal (Smith et al., 1989a

Dibromochloroacetic acid (NTP, National Toxicology Program, 2000)

Bromodichloroacetic acid

Dichloroacetonitrile

LE Rat, G-tricap, primarily septal defects, also eye defects (Smith et al., 1989b)

Trichloroacetonitrile (TCAN) LE rat, G-tricap, mainly levocardia, eptal defect and not significant, primarily common carotid trunk (Smith et levocardia, also eye defects al., 1988)

LE rat, G-tricap, 1 dose, mainly defect between ascending aort and right ventricle,

interventricular septal defect right-sided and ringed aortic

arch (Christ et al., 1996)

Bromochloro-acetonitril
SD rat-DW, MTD not achieved CD-1 mouse, day 8 (3-6 somites), also (NTP, National Toxicology neural tube, ${ }^{\mathrm{b}}$ pharyngeal arch and eye levocardia, also interventricula defects (Hunter et al., 1996)
D rat, G-water (Fisher et al.

rat, DW, MTD not achieved

levocardia, also eye defects

CD-1 mouse, day 8 (3-6 somites), also neural tube, pharyngeal arch and eye defects (Hunter et al., 1996)

Christ et al., 1996) defects at same concentration as heart defects; also pharyngeal arch, eye; and defects at same concentration as heart defects; also pharyngeal arch and eye et al., 2006a)$$
-
$$

DCA induction of ventricular septal defects was increased by low folate maternal diets in the SD rat (Rogers et al., 2005).

as dose additive with DBA and/or DCA on development of rat embryo in culture (Andrews et al., 2004)

Inhibited neural crest cell migration in cultured explants from rat and mouse embryos (Andrews et al., 2001; Hunter et al., 2001)

Induces apoptosis in mouse embryos (Ward et al., 2000)

Metabolites of $\mathrm{BCA}$ were much less potent than $\mathrm{BCA}$ in mouse embryo culture (Hunter and Rogers, 1999).

BCA caused changes in gene expression in couse entro (Karoly et at, 2004), mouse enbyo culf B) (Hunter et al, 2005). (pro Anase B) (Hunter et al., 2005).

An antagonist of an upstrean regulator of Akt caused similar cardiac defects as did BCA in mouse embryo culture (Hunter et al., 2005).

SD rat, day 10 (4-7 somites), hypoplasia LE rat, G, antagonistic interaction with DCA of prosencephalon, eye defects, decreased yolk sac diameter (Saillenfait et al., 1995)

(Smith

Has similar potency to its metabolites in mouse embryo culture (Hunter and Rogers, 1999)

D-1 mouse, day 8 (3-6 somites), yolk sac neural tube defects (Hunter et al., 2006a) CD-1 mouse, day 8 (3-6 somites), yolk sa defects; neural tube defects but NS (Hunter

(1)

right ventricle defect, also interventricular septal defect an
levocardia (Christ et al., 1995) ccount for developmental toxicity (Chri

Metabolism to cyanide does not appear to account for developmental toxicity (Christ et al., 1995; Smith et al., 1988).

L rat, G, accumulation of radioactivity in maternal liver and in fetus from two to three daily doses of ${ }^{14} \mathrm{C}$-TCAN was higher for the trich dose of 14 crichloromethyl carbon (C2) than the cyano with. Acunlan in en (Gordh the (Gordon et al., 1991). account for developmental toxicity (Chris et al., 1995; Smith et al., 1988). et al., 1995; Smith et al., 1988)

Metabolism to cyanide does not appear to 


\section{Dibromoacetonitrile}

Chloroacetonitrile

1,1,3,3,-Tetrachloropropanone -

Chlorine dioxide-disinfected Suggestive data:

Human, DW, epi (Cedergren

Chlorine dioxide et al., 2002)

Chlorite

\section{Chloral hydrate}

Dichloromethan

Rabbit, Inhal., MTD not

chieved (Sikov et al 1981)

Rabbit, Inhal. (Breslin et al.,

1990)
CF-1 mouse, rabbit, G-corn oil -

(John et al., 1982)

Human, DW, epi (Kallen and

Robert, 2000)

Rat, DW, but only 6-8 dams/ dose (Suh et al., 1983)

SD rat, DW, but only 6-8 dams/ dose, MTD not achieved (Suh et al., 1983)

Rabbit, DW, MTD may not have been achieved (Harrington et al., 1995).

SD rat, DW, also materna

toxicity (body weight loss and

hemolysis) and greatly

decreased water and food intake

(Couri et al., 1982)

SD rat, DW (Johnson et al., 1998) SD rat, day 10 (4-7 somites), pericardial

dilatation, decreased yolk sac circulation at

highest exposure; more sensitive endpoints

were prosencephalic hypoplasia, eye defects

and decreased yolk sac diameter (Saillenfait et al., 1995).

LE rat, Inhal. (Hardin and

Manson, 1980)

SD rat, Swiss Webster mouse,

Inhal. (Schwetz et al., 1975)

SD rat, 10.5 days (12-15 somites)

craniofacial but not cardiac, but effects

may be due to severe effect on yolk sac

vascus).

Wistar rat, Inhal. (Sikov et al.,

1981)
Metabolism to cyanide does not appear to account for developmental toxicity (Chris et al., 1995; Smith et al., 1988).

Metabolism to cyanide does not appear to account for developmental toxicity (Christ tal., 1995; Smith et al., 1988).

Generally, toxicity is considered due to Dxidative properties (U.S. EPA, 2000b). Decreased the levels of circulating thyroxine in monkeys and rats, and in developmental study in rats, possibly though oxidation of dietary iodide in the GI tract, resulting in reactive species that iodinate organic matter to form potentially thyroid inhibitory compound (Bercz et al., 1986; Orme et al., 1985).

Generally, toxicity is considered due to oxidative properties (U.S. EPA, 2000b).

The metabolite trichloroethanol has sedative effects. Other metabolites are trichloroacetic and possibly small amounts of dichloroacetic acid (U.S. EPA, 2000a).

Generally, toxicity may be due to P450 metabolism to a reactive intermediate and carbon monoxide, and to direct conjugation of dichloromethane with GSH to form a bioactive product. Also, the parent compound may enter cell membranes and thereby interfere with signat transis and (ATSDR, 2000).

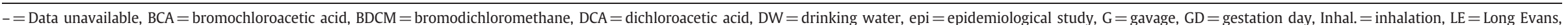
$-=$ Data unavailable, $\mathrm{BCA}=$ bromochloroacetic acid, $\mathrm{BDCM}=$ bromodichloromethane, $\mathrm{DCA}=$ dichloroacetic acid, $\mathrm{DW}=$ drinking water, epi $=$ epidemiological study,
$\mathrm{MTD}=$ maximum tolerated dose, $\mathrm{NS}=$ not statistically significant, $\mathrm{SD}=$ Sprague-Dawley, $\mathrm{TCA}=$ trichloroacetic acid, $\mathrm{TCAN}=$ trichloroacetonitrile, tricap $=$ tricaprylin.

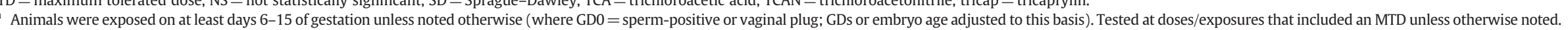

b Aunter et al. (1996) classified prosencephalic hypoplasia and neural tube closure defects together under the category neural tube defects.

Generally, toxicity may be due to the alkylating (methylating) properties of bromomethan
(ATSDR, 1992; Vogel and Nivard, 1994) 
the dam, as caused by bromodichloromethane. We conclude that the MOA for the haloacetic acids and haloacetonitriles that caused fulllitter resorption in Long-Evans rats likely differs from that of the trihalomethanes and could be secondary to embryofetal toxicity.

A mixture of the five haloacetic acids regulated in drinking water, tested using proportions similar to those found in drinking water in F344 rats by gavage on GD 6-20, resulted in suggestive evidence that this mixture may cause pregnancy loss in this strain/stock (Narotsky et al., 2011). A non-significant incidence of full-litter resorption occurred at the mid dose level (versus no full-litter resorptions in controls or at the low dose level). A high incidence of full-litter resorption occurred in surviving dams at the high dose level, but four (of 15) died, indicating severe maternal toxicity. Based on this evidence, it would be useful to further evaluate the five haloacetic acids regulated in drinking water and the four other common haloacetic acids in the F344 rat.

The remaining two DBPs with positive results for full-litter resorption produced the effect at doses highly toxic to the dams in rat strains/stocks of lesser or unknown sensitivity (chlorite in Sprague-Dawley rats [Couri et al., 1982]; bromomethane in RIV-TOX rats [Peters et al., 1981]). Thus, the effect in these studies probably was secondary to severe maternal toxicity and does not appear at this time to be similar to the MOA of bromodichloromethane.

\section{Cardiovascular malformations}

Several retrospective epidemiologic studies have reported increased risks for cardiovascular malformations from exposure to treated drinking water. In a nationwide study of Norwegian births, Hwang et al. (2002) reported no statistically significant association between exposure of pregnant women to chlorinated water of low, medium, or high color and the occurrence of total cardiac defects in their infants. The ORs for ventricular septal defects, however, were increased following exposure to chlorinated water of medium color $(\mathrm{OR}=1.63,95 \% \mathrm{CI}=1.02-2.58)$ or high color $(\mathrm{OR}=1.81,95 \%$ $\mathrm{CI}=1.05-3.09$ ). Color has been positively correlated with the concentration of dissolved organic compounds in Norwegian waters (Hongve and Andersen, 1991). Hwang et al. (2002) expected that exposure to DBPs was more likely when water with dissolved organic compounds was chlorinated. Color, however, is a crude indicator of DBP concentrations as it also might reflect metallic ions and other compounds present in drinking water. Hwang et al. (2008), in a nationwide study of Taiwanese births, reported an increased risk of ventricular septal defects ( $\mathrm{OR}=1.81,95 \% \mathrm{CI}=0.94-4.07)$ for exposure to trihalomethane drinking water concentrations $\geq 20 \mu \mathrm{g} / \mathrm{L}$ relative to those $<4 \mu \mathrm{g} / \mathrm{L}$. In a study of birth defects in England and Wales, Nieuwenhuijsen et al. (2008) reported excess risk for ventricular septal defects $(\mathrm{OR}=1.43,95 \% \mathrm{CI}=1.00-2.04)$ from exposure to trihalomethanes levels $\geq 60 \mu \mathrm{g} / \mathrm{L}$ (mean $=72.2 \mu \mathrm{g} / \mathrm{L}$ ) as compared with $<30 \mu \mathrm{g} / \mathrm{L}$ (mean $=16.4 \mu \mathrm{g} / \mathrm{L}$ ). As summarized in Table 3, this specific cardiac defect was observed in rats administered some of the haloacetic acids and haloacetonitriles orally.

Bove et al. (1995) reported an association ( $O R=1.83,90 \%$ $\mathrm{CI}=0.97-3.29)$ between major cardiac defects and total trihalomethane levels $>80 \mu \mathrm{g} / \mathrm{L}$ (vs. $\leq 20 \mu \mathrm{g} / \mathrm{L}$ ) in northern New Jersey. In addition to containing DBPs, these drinking waters were contaminated with organic solvents from landfills, industrial waste, and underground storage tanks.

Chisholm et al. (2008) conducted a study of births in Perth, Australia, where trihalomethane levels are higher than is usual in other countries. The authors reported that the risk for any cardiovascular birth defect was increased $(\mathrm{OR}=1.62,95 \% \mathrm{CI}=1.04-2.51)$ for the high exposure group (total trihalomethane $\geq 130 \mu \mathrm{g} / \mathrm{L}$; average $=137 \mu \mathrm{g} / \mathrm{L}$ ) as compared with the referent group (total trihalomethane $<60 \mu \mathrm{g} / \mathrm{L}$; average $=54 \mu \mathrm{g} / \mathrm{L}$ ). A main study limitation was that there was no unexposed or low exposed population to serve as the referent group, as the reference population $(<60 \mu \mathrm{g} / \mathrm{L})$ was comparable to intermediate and high exposure groups in other studies. The authors stated that preliminary analyses of the haloacetic acids and haloacetonitriles indicated that concentrations were very low "by international standards," so monitoring for these DBPs was discontinued.

Nieuwenhuijsen et al. (2008), in the previously mentioned study of birth defects in England and Wales, reported an increased risk for a restricted group of major cardiac defects $(\mathrm{OR}=1.18,95 \% \mathrm{CI}=1.00$ 1.39) from exposure to bromoform at concentrations $\geq 4 \mu \mathrm{g} / \mathrm{L}$ (mean $=6.7 \mu \mathrm{g} / \mathrm{L}$ ). The referent group was exposed to $<2 \mu \mathrm{g} / \mathrm{L}$ of bromoform in drinking water. Other epidemiologic studies of drinking water exposure to total or individual trihalomethanes in Canada and the United States (Dodds and King, 2001; Dodds et al., 1999; Shaw et al., 2003) or exposure to chlorinated water in Norway and Sweden (Kallen and Robert, 2000; Magnus et al., 1999) have not detected increased risk for cardiovascular defects.

Cedergren et al. (2002), in a study of congenital cardiac birth defects in a Swedish county, reported that chlorine dioxide-disinfected municipal drinking water was a statistically significant risk factor for the development of cardiac defects. This conclusion was based on the finding that the OR for cardiac defects from disinfection with hypochlorite was not elevated $(\mathrm{OR}=0.85,95 \% \mathrm{CI}=0.60-1.21)$, but an association was reported between cardiac defects and disinfection with both chlorine dioxide and hypochlorite $(\mathrm{OR}=1.61 ; 95 \% \mathrm{CI}=1.00$ 2.59), as compared with no chlorination. Comparison of the combined chlorine dioxide and hypochlorite treatment with hypochlorite alone further implicated chlorine dioxide disinfection (OR $=1.85,95 \%$ $\mathrm{CI}=1.42-2.39$ ). Trihalomethane concentrations $>10 \mu \mathrm{g} / \mathrm{L}$ in drinking water were also statistically significantly associated with cardiac defects $(\mathrm{OR}=1.30,95 \% \mathrm{CI}=1.08-1.56)$ relative to concentrations $\leq 10 \mu \mathrm{g} / \mathrm{L}$. Concentrations of DBPs (other than total trihalomethanes) or residual chlorine dioxide were not determined. This study is limited because the drinking waters contained very low trihalomethane concentrations and a narrow exposure gradient.

The epidemiologic studies which reported associations did not provide information regarding a MOA for cardiovascular birth defects and did not include an examination of DBP classes or individual DBPs other than the trihalomethanes, which were associated with cardiovascular defects. Other DBPs not examined in these studies may confound the reported associations if they are correlated with trihalomethane concentrations and are risk factors for the outcomes of interest.

Studies of the individual trihalomethanes in experimental animals, treated on at least GD 6-15 (organogenesis), have not shown increased incidences of cardiac malformations. These studies were conducted in rats, mice, and rabbits administered the chemicals by gavage, and in rats and mice exposed to chloroform by inhalation, as listed in Table 3. No cardiac developmental toxicity studies of trihalomethane mixtures similar to those in treated drinking water have been reported in experimental animals.

Some of the haloacetic acids have shown evidence of heart defects when administered to rats by gavage. Suggestive evidence was reported for monobromoacetic acid and monochloroacetic acid in Long-Evans rats, but cardiovascular malformation data were reported only as number of fetuses with each type of cardiac defect, rather than as litter-based values (Randall et al., 1991; Smith et al., 1990). Two studies of dichloroacetic acid reported fetal heart defects following gavage administration to Long-Evans rats (Epstein et al., 1992; Smith et al., 1992a). Two studies of trichloroacetic acid, one using drinking water administration to Sprague-Dawley rats (Johnson et al., 1998) and the other using gavage administration to Long-Evans rats (Smith et al., 1989a), also reported heart defects in the fetuses.

Negative results for cardiovascular malformations in the SpragueDawley rat also have been reported from oral exposure to monochloroacetic acid, dichloroacetic acid, bromochloroacetic acid, tribromoacetic acid, trichloroacetic acid, and dibromochloroacetic acid 
(Fisher et al., 2001; Johnson et al., 1998; NTP, National Toxicology Program, 1998b,c, 2000). Except for the study by Fisher et al. (2001), these studies exposed the animals through drinking water, and some did not attain a MTD. The negative studies used lower dosage levels than did the positive studies and, in the case of drinking water studies, delivered the dose intermittently over time rather than as a single daily bolus. Thus, the difference between the positive and negative studies does not appear to be due to strain/stock of rat, since both positive and negative results were obtained for trichloroacetic acid in Sprague-Dawley rats. Rather, the difference appears to be a function of dose level.

The haloacetonitriles that have been tested adequately (see Methods) in developmental toxicity studies (i.e., dichloroacetonitrile, trichloracetonitrile, and bromochloroacetonitrile) have caused cardiovascular defects in gavage studies in Long-Evans rats (Christ et al., 1995, 1996; Smith et al., 1988, 1989b). There is some concern regarding the choice of vehicle used in the haloacetonitrile gavage studies. Tricaprylin, a triglyceride vehicle, was used due to the volatility and instability of the haloacetonitriles in water and the high concentrations required to achieve sufficient doses in a small volume. In the gavage developmental toxicity studies on the haloacetonitriles, tricaprylin controls had slight elevations in some indices of developmental toxicity relative to water controls, but these were not consistent across the studies and few were statistically significant (Christ et al., 1995, 1996; Smith et al., 1988, 1989b). A limited comparison of the developmental toxicity of trichloroacetonitrile in tricaprylin versus trichloroacetonitrile in corn oil (Christ et al., 1996) suggested that the developmental toxicity of trichloroacetonitrile, including induction of cardiac defects, was greater in tricaprylin than in corn oil. The suitability of corn oil as a vehicle has been questioned, however, because the pharmacokinetics and toxicity of chlorinated compounds have been shown to be statistically significantly different in corn oil than in aqueous vehicles (Kim et al., 1990a,b; Lilly et al., 1994; Narotsky et al., 1997a; Withey et al., 1983).

As summarized above and in Table 3, positive results for cardiovascular malformations have been observed for several of the haloacetic acids in rats in vivo (Epstein et al., 1992; Randall et al., 1991; Smith et al., 1990, 1992a), for all nine haloacetic acids of interest in mouse embryo culture (Hunter et al., 1996, 2006a,b), and for the three dihaloacetic acids in rat embryo culture (Andrews et al., 2004). Positive results for cardiovascular malformations also were observed for three haloacetonitriles in rats in vivo (Christ et al., 1995, 1996; Smith et al., 1988, 1989b), but the haloacetonitriles have not been tested in embryo culture. In both the whole embryo culture studies and the in vivo animal studies, the observed pattern of heart defects and craniofacial defects (including eye defects) suggests a hypothesis that the haloacetic acids and haloacetonitriles (at least trichloroacetonitrile) may exhibit a common MOA by affecting neural crest cells.

The cranial and cardiac neural crest cells migrate and differentiate into structures of the face and the musculoconnective tissues of the large arteries emerging from the heart, the membranous portion of the ventricular septum, and the septum between the pulmonary artery and the aorta. Further studies with mouse and rat embryo neural crest explants showed that some dihaloacetic acids (dibromoacetic acid and bromochloroacetic acid, but not dichloroacetic acid) affected neural crest cell development and migration at concentrations that alter development in whole embryo culture (Andrews et al., 2001; Hunter et al., 2001). Neural crest-mediated heart defects, however, occur in the outflow tracts of the heart and do not account for the full range of heart defects seen in in vivo studies in the rat. We suggest that a key event further upstream in development could be responsible for the full range of heart defects. Thus, key events for the cardiovascular malformations resulting from exposure to the haloacetic acids and haloacetonitriles are uncertain. For most of these DBPs, direct effects on the embryo seem likely, but for dichloroacetic acid, which produces widespread metabolic effects (see Table 3), there could be some contribution through effects on the dam.

We note that the only epidemiologic studies that reported associations of disinfected drinking water or DBPs (the trihalomethanes or bromoform) with cardiovascular malformations did not investigate potential associations with the types of DBPs (haloacetic acids or haloacetonitriles) that cause these effects in rodents. Swan and Waller (1998) suggested that trihalomethanes, which were until recently the only DBPs required to be monitored, may be proxies for other, possibly nonvolatile, etiologic agent(s) in the finished water supply. More recent U.S. studies of drinking water DBPs suggest that total haloacetic acid concentrations were correlated with reported total trihalomethane concentrations across different water systems (Savitz et al., 2005) or seasons (Porter et al., 2005); other DBP classes were not investigated. Additional studies are needed to further investigate these relationships.

\section{Neural tube defects}

The concern for an association between DBPs and neural tube defects stems from the results of some epidemiological studies. One case-control study of neural tube defects (i.e., spina bifida, anencephaly, encephalocele) examined registry data for all births from 1993 to 1994 in New Jersey in relation to public water sampling during the first trimester of pregnancy (Klotz and Pyrch $(1998,1999)$. The authors reported that when cases were restricted to mothers with known residence at conception and to isolated neural tube defects (i.e., other defects not present), a statistically significant association $(\mathrm{OR}=2.1,95 \% \mathrm{CI}=1.1-4.0)$ was detected between neural tube defects and the highest tertile $[\geq 40 \mathrm{ppb}(\mu \mathrm{g} / \mathrm{L})]$ versus the lowest tertile $(\leq 5 \mathrm{ppb})$ of total trihalomethane exposure. None of the individual trihalomethanes (also determined from public water sampling) were statistically significantly associated with neural tube defects in comparisons of the highest versus lowest exposure tertiles. In this study, trihalomethane exposure generally was determined by public water sampling at points in the distribution system representative of residences. Additional sampling and analysis of residential tap water from "index residences" were performed for the trihalomethanes 1 year after the first trimester of pregnancy; for residences served by water systems that may have included surface water sources, analyses also included the haloacetic acids and haloacetonitriles. For the residential tap water data on total trihalomethanes, and cases restricted to isolated neural tube defects, an association was detected for the highest exposure tertile relative to the lowest tertile $(\mathrm{OR}=1.9,95 \% \mathrm{CI}=1.0-4.0)$. The OR for cases restricted to mothers with known residence at conception and also to isolated neural tube defects was not reported. In the highest tertile of total trihalomethane exposure, an association with neural tube defects was seen only in the cases where the mothers did not take daily multivitamin or folate supplements during the 3 months prior to pregnancy. The authors stated in their 1999 publication that results were not markedly different when analyses controlled for volatile organic compound (VOC) contamination of the drinking water, which was generally very low (with very few cases or controls exposed to $\geq 1 \mathrm{ppb}$ of any individual VOC).

Bove et al. (1995) reported an association of neural tube defects with total trihalomethanes $(\mathrm{OR}=2.96,90 \% \mathrm{CI}=1.26-6.62)$ in infants of mothers exposed to $>80 \mathrm{ppb}$ in drinking water (in comparison with $\leq 20 \mathrm{ppb}$ ). This case-control study was performed in Northern New Jersey where water supplies, in addition to containing DBPs, were contaminated with organic solvents from landfills, industrial waste and underground storage tanks. VOC concentrations were low in this study as well, with few cases exposed above $1 \mathrm{ppb}$. No information regarding use of daily multivitamin or folate supplements was identified. Although it was only based on only two cases, there was some suggestive evidence of an association of neural tube defects with 
exposure to carbon tetrachloride. Other epidemiologic studies reported no association of chlorinated drinking water with neural tube defects in Norway (Hwang et al., 2002; Magnus et al., 1999) and Sweden (Kallen and Robert, 2000) or for total trihalomethane exposures and risk of neural tube defects in California (Shaw et al., 2003).

One study reported an association of an individual trihalomethane, bromodichloromethane, with neural tube defects in humans. In a retrospective cohort study in Nova Scotia, Canada, Dodds and King (2001) reported an increased relative risk of $2.5(95 \% \mathrm{CI}=1.2-5.1)$ for neural tube defects associated with maternal exposure to bromodichloromethane concentrations of $\geq 20 \mu \mathrm{g} / \mathrm{L}$ (as compared with exposure to $<\mu \mathrm{g} / \mathrm{L}$ ) in chlorinated drinking water during pregnancy. The study included both live and still births and also data from pregnancies terminated for prenatally diagnosed congenital anomalies. No association of bromodichloromethane (Klotz and Pyrch, 1998; Shaw et al., 2003), dibromochloromethane (Shaw et al., 2003), or chloroform (Dodds and King, 2001; Klotz and Pyrch, 1998) with neural tube defects was observed in epidemiologic studies in California and New Jersey.

The only epidemiologic data examining associations of other DBPs with neural tube defects were from Klotz and Pyrch $(1998,1999)$ for the haloacetic acids and haloacetonitriles, determined by residential tap water sampling and analysis 1 year after the first trimester as described previously. No statistically significant association with neural tube defects was seen for the highest tertile ( $\geq 35 \mathrm{ppb}$ ) versus the lowest $(<3 \mathrm{ppb})$ tertile of haloacetic acid exposure ( $\mathrm{OR}=1.2,95 \%$ $\mathrm{CI}=0.5-2.6)$ or for the highest tertile $(\geq 3.0 \mathrm{ppb})$ versus the lowest $(<0.5 \mathrm{ppb})$ tertile of total haloacetonitriles $(\mathrm{OR}=1.3,95 \% \mathrm{CI}=0.6-$ 2.5 ) in this study. Narrow exposure gradients and limited statistical power may have impacted the ability to detect an association, if one existed, between neural tube defects and other DBPs in this study.

The only MOA data directly relevant to the potential association of DBPs with neural tube defects is the observation in a case-control study that an association of exposure to total trihalomethanes with neural tube defects was seen only in the cases where the mothers did not take daily multivitamin or folate supplements during the 3 months prior to pregnancy (Klotz and Pyrch, 1998, 1999). Folic acid or folate is a coenzyme involved in single carbon transfers in the metabolism of nucleic acids and amino acids (Institute of Medicine, 1998; Padmanabhan, 2006). As discussed in these reviews, folic acid is known to be required for DNA synthesis, and its deficiency has been associated with neural tube defects. Supplementation with this vitamin lowers the risk of neural tube defects in humans. Despite these observations, the etiology of neural tube defects is poorly understood and appears highly complex. Genetic, nutritional, and environmental factors including drug and chemical exposures have been implicated. Investigations of genetic variation in enzymes involved in folic acid pathways, including the 5,10-methylenetetrahydrofolate reductase (MTHFR) gene, have not shown conclusively that these are causal factors for neural tube defects, suggesting a multifactorial etiology. Thus, a potential MOA for DBP induction of neural tube defects involves folic acid pathways, but the mechanism whereby folic acid prevents neural tube defects is not known, and the evidence associating DBPs with neural tube defects is weak. Thus, no MOA is established for DBP induction of neural tube defects.

In addition, none of the in vivo studies of developmental toxicity in laboratory mammals detected statistically significant incidences of neural tube defects as a consequence of exposure to any of the individual DBPs. These in vivo studies were conducted in rats, mice, or rabbits on all four of the individual trihalomethanes, on some of the individual haloacetic acids and haloacetonitriles, and on the remaining selected DBPs. All of these studies reported negative results or detected only single instances of neural tube defects. The studies are listed in Table 4. Studies that may not have been adequate to detect neural tube effects are those where the MTD was not achieved, too few pregnant dams were studied, or examinations were performed only postnatally; Table 4 highlights these limitations.

Only the in vitro whole embryo culture studies of mouse and rat embryos reported neural tube defects, and these defects generally occurred in the presence of yolk sac defects including reduced diameter and circulation, and/or in the presence of multiple other growth and structural defects, as noted in Table 4. The data regarding neural tube defects in the whole embryo culture studies are not reported uniformly across studies: prosencephalic hypoplasia was considered a neural tube defect in one set of data and combined with neural tube closure defects in the data tabulation (Hunter et al., 1996), and was recorded in other data series as a separate defect that may be a defect of neural tube expansion or may be simply a growth retardation reflecting overall growth. Studies reporting positive results for neural tube defects or neural tube closure defects are reported in the positive column of Table 4, whereas those reporting only prosencephalic hypoplasia (and no closure defects) in the presence of overall growth retardation are reported in the negative column of the table.

Thus, as discussed previously, although a few epidemiology studies have raised concerns regarding an association of neural tube defects with exposure to DBPs (Bove et al., 1995; Dodds and King, 2001; Klotz and Pyrch, 1998, 1999), the epidemiologic evidence associating DBPs with neural tube defects is weak. In addition, the available data are inadequate to outline key steps in an MOA for this effect and the in vivo animal data do not provide support for neural tube defects as an effect of exposure to any single DBP.

\section{Low birth weight or intrauterine growth retardation}

Several epidemiologic studies have reported an association with small for gestational age (i.e., intrauterine growth retardation) or low birth weight infancy and exposure to DBPs, primarily the trihalomethanes and the haloacetic acids, both as classes and individual chemicals. These studies are listed in Table 5 and the more recent U.S. studies are discussed in detail later in this section. Intrauterine growth retardation/restriction or small for gestational age is generally defined as birth weight below the 10th percentile for gestational age adjusted for certain covariates such as sex and race. Low birth weight is generally defined as birth weight $<2500 \mathrm{~g}$ and term low birth weight is generally defined as birth weight $<2500 \mathrm{~g}$ for infants of $\geq 37$ weeks gestation. Small for gestational age is generally considered a better indicator of fetal growth since low birth weight is influenced by both fetal growth rate and duration of gestation.

One epidemiologic study provides some evidence for a potential MOA for fetal growth restriction outcomes. In a case-control study in Montreal, Quebec, Canada, Infante-Rivard (2004) reported that exposure to treated drinking water resulted in an increased risk of intrauterine growth restriction (retardation) associated with average total trihalomethane exposure above the 90th percentile (corresponding to $29.5 \mu \mathrm{g} / \mathrm{L}$ ), but only in infants (cases $=45$ and controls $=37$ ) with a specific variant CYP2E1 gene [G1259C (a G-to-C substitution at position 1259 in the promoter) that defines the allele CYP2E1*5]. The adjusted OR for this effect was $13.2(95 \% \mathrm{CI}=1.2-$ 146.7). No association was seen in the infants with wild type CYP2E1 or when cases and controls were not subdivided on the basis of genetic polymorphisms. The authors determined that the mother's CYP2E1 gene was not associated with this outcome, and a 5,10MTHFR gene variant (C677T) in newborns or mothers also was not associated with this outcome. CYP2E1 is the primary enzyme that metabolizes low doses of the trihalomethanes. As reviewed by Infante-Rivard (2004), the CYP2E1 gene variant G1259C, located in the regulatory region, is associated with hyperinduction, which would be expected to increase the amount of enzyme compared with individuals without the mutation, and consequently increase the 
metabolic activation of trihalomethanes. This finding suggests that if there is an effect of trihalomethanes on intrauterine growth retardation, it may be related to (as yet undetermined) damage from toxic intermediates resulting from increased metabolic activation of the trihalomethanes in genetically sensitive fetuses. Christian et al. (2001b) and Withey and Karpinski (1985) have shown that dibromochloromethane, administered to pregnant rabbits orally, and chloroform, administered to pregnant rats by inhalation, reach the fetus, and therefore would be available for potential metabolic activation by fetal CYP2E1, at least in these species. Generally, toxicity of the trihalomethanes may be mediated through metabolism to reactive and toxicity intermediates (ATSDR, 2003; ILSI, 1999; U.S. EPA, 2001).

Epidemiologic studies that reported positive results for intrauterine growth retardation usually focused on DBP exposure during the third trimester or the entire pregnancy. A few epidemiologic studies have shown an association of intrauterine growth retardation with DBP exposure in the second trimester (trihalomethanes, Lewis et al., 2006 and Wright et al., 2003; monobromoacetic acid, Porter et al., 2005). These findings support the hypothesis proffered by Porter et al. (2005) that although the third trimester is the most important for fetal weight gain, insults prior to the third trimester may impact fetal growth by interfering with cell proliferation, which occurs mainly prior to the third trimester.

We did not identify additional research on these possible steps in a MOA for this adverse outcome. Thus, the data currently available for this endpoint do not adequately characterize the MOA for intrauterine growth retardation. Nevertheless, many of the more recent U.S. epidemiologic studies of this outcome support it as a developmental effect of concern for DBP exposure. These more recent U.S. studies are reviewed below.

In a study of birth weight in 36,529 singleton births in a Massachusetts population that received water from a single water utility during 1999-2001, Lewis et al. (2006) reported an association between high average total trihalomethane exposure in drinking water $(\geq 70 \mu \mathrm{g} / \mathrm{L})$ during the second trimester of pregnancy and an increased risk of term low birth weight for all races/ethnicities combined $(\mathrm{OR}=1.50,95 \% \mathrm{CI}=1.07,2.10)$. The increase for Caucasians alone was not statistically significant $(\mathrm{OR}=1.37,95 \% \mathrm{CI}=0.80$, $2.36)$, but for all minority women combined $(n=15,103)$ was $60 \%$ $(\mathrm{OR}=1.60,95 \% \mathrm{CI}=1.03,2.47)$. No statistically significant increase in risk of term low birth weight was detected for first or third trimester exposures.

Wright et al. (2003) examined the effect of trimester-specific and pregnancy average total trihalomethane exposure on 56,513 singleton births in Massachusetts during 1990. They reported increased ORs for small for gestational age for second trimester ( $O R=1.13,95 \%$ $\mathrm{CI}=1.03-1.24$ ) and for pregnancy average ( $\mathrm{OR}=1.14,95 \%$ $\mathrm{CI}=1.02-1.26)$ total trihalomethane concentrations $>80 \mu \mathrm{g} / \mathrm{L}$ as compared with $\leq 60 \mu \mathrm{g} / \mathrm{L}$. Term low birth weight was not associated with total trihalomethane exposure.

Wright et al. (2004) reported on a cohort of Massachusetts women giving birth between 1995 and 1998 for whom third-trimester DBP data were available. Outcome data for 196,000 singleton births were examined. Reduced mean birth weight was associated with drinking water exposure to concentrations of total trihalomethane $>40 \mu \mathrm{g} / \mathrm{L}$ and chloroform $>20 \mu \mathrm{g} / \mathrm{L}$. An increased risk of small for gestational age births was associated with concentrations of total trihalomethanes $>33-74 \mu \mathrm{g} / \mathrm{L}(\mathrm{OR}=1.06,95 \% \mathrm{CI}=1.02-1.10)$ and $>74-163 \mu \mathrm{g} / \mathrm{L} \quad(\mathrm{OR}=1.13,95 \% \mathrm{CI}=1.07-1.20)$, chloroform $>63$ $135 \mu \mathrm{g} / \mathrm{L} \quad(\mathrm{OR}=1.11,95 \% \mathrm{CI}=1.04-1.17)$, and bromodichloromethane $>5-13 \mu \mathrm{g} / \mathrm{L}(\mathrm{OR}=1.10,95 \% \mathrm{CI}=1.07-1.14)$ and $>13-$ $46 \mu \mathrm{g} / \mathrm{L}(\mathrm{OR}=1.15,95 \% \mathrm{CI}=1.08-1.22)$. Increased risks for adverse fetal growth outcomes were not detected for the five regulated haloacetic acids as a group, dichloroacetic acid or trichloroacetic acid exposures.
Gallagher et al. (1998) investigated third trimester exposure to total trihalomethanes in Colorado and reported an association between term low birth weight and exposure to high levels $(\geq 61 \mathrm{ppb})$ of total trihalomethanes in the maternal drinking water as compared with $\leq 20 \mathrm{ppb}(\mathrm{OR}=5.9,95 \% \mathrm{CI}=2.0-17.0)$.

Hoffman et al. (2008) reported an increased risk of delivering a small for gestational age infant in women exposed to average trihalomethane concentrations of $\geq 80 \mu \mathrm{g} / \mathrm{L}$ as compared with those exposed to $<80 \mu \mathrm{g} / \mathrm{L}$ in tap water during the third trimester (risk ratio $=2.0,95 \% \mathrm{CI}=1.1-3.6$ ). [Other results from this prospective study were reported by Savitz et al. $(2005,2006)$ and are reviewed in the spontaneous abortion/full-litter resorption section of this paper.] Hoffman et al. (2008) did not detect an association between small for gestational age and trihalomethane exposure through showering and bathing, or between this outcome and total haloacetic acid concentration in tap water or consumption through tap water.

In a study of 15,315 births in a Maryland county, Porter et al. (2005) investigated the possible association between intrauterine growth retardation and exposure to the trihalomethanes and the five haloacetic acids ("HAA5") that have drinking water regulations (monochloro-, dichloro-, and trichloroacetic acid; monobromo- and dibromoacetic acid). The authors evaluated exposure to total trihalomethanes, HAA5, and to individual compounds for each trimester and also the entire pregnancy. No consistent statistically significant association with intrauterine growth retardation was seen for these two classes of DBPs or for the individual chemicals, and no evidence of a dose-response relationship was observed. The results for HAA5 and three of the individual haloacetic acids, however, were suggestive of potential effects. An association with intrauterine growth retardation was seen for the third trimester for the second $(\mathrm{OR}=1.20,95 \% \mathrm{CI}=1.01-1.68)$, third $(\mathrm{OR}=1.41,95 \% \mathrm{CI}=1.11-$ $1.81)$ and fifth $(\mathrm{OR}=1.34,95 \% \mathrm{CI}=1.04-1.71)$ quintiles of total HAA5 exposure (first quintile $=$ referent), but no dose-response was evident. Statistically significant associations with intrauterine growth retardation for second trimester exposure to monobromoacetic acid were observed for the third $(\mathrm{OR}=1.30,95 \% \mathrm{CI}=1.02-1.65)$ and fourth $(\mathrm{OR}=1.30,95 \% \mathrm{CI}=1.02-1.66)$ quintiles but not the fifth (highest) quintile of exposure. Associations with intrauterine growth retardation were reported for second trimester exposure to monochloroacetic acid for the third quintile $(\mathrm{OR}=1.27,95 \% \mathrm{CI}=1.00-1.61)$ and third trimester exposure to dichloroacetic acid for the second quintile $(\mathrm{OR}=1.29,95 \% \mathrm{CI}=1.02-1.64)$ of exposure. Statistically significant associations with intrauterine growth retardation for third trimester exposure to trichloroacetic acid were seen for the second $(\mathrm{OR}=1.30,95 \%$ $\mathrm{CI}=1.01-1.65)$ and third $(\mathrm{OR}=1.34,95 \% \mathrm{CI}=1.05-1.71)$ quintiles and ORs were consistently $\geq 1.2$ regardless of exposure level.

Similarly, Hinckley et al. (2005), in a study of 48,119 birth outcomes in an Arizona community, found no evidence of an association between drinking water exposure to total trihalomethanes, or to three specific trihalomethane compounds, with intrauterine growth retardation or term low birth weight; bromoform was not evaluated because drinking water concentrations of this compound were very low. The authors observed associations with exposure to specific haloacetic acids but not HAA5, as follows: (1) associations between exposure to $\geq 5 \mu \mathrm{g} / \mathrm{L}$ dibromoacetic acid ( $\mathrm{OR}=1.49,95 \% \mathrm{CI}=1.09$ 2.04 ) or to dibromoacetic acid analyzed as a continuous variable $(\mathrm{OR}=1.17,95 \% \mathrm{CI}=1.03-1.32)$ during the third trimester with increased risk for term low birth weight; (2) associations between dibromoacetic acid exposure at $\geq 5 \mu \mathrm{g} / \mathrm{L}$ during gestation weeks 33-36 $(\mathrm{OR}=1.49,95 \% \mathrm{CI}=1.10-2.02)$ and at $3.5-5 \mu \mathrm{g} / \mathrm{L}$ (but not $\geq 5 \mu \mathrm{g} / \mathrm{L}$ ) during gestation weeks $37-40(\mathrm{OR}=1.38,95 \% \mathrm{CI}=1.02-1.86)$ with an increased risk for term low birth weight; (3) an association of dibromoacetic acid analyzed as a continuous variable in both gestation weeks 33-36 ( $\mathrm{OR}=1.11,95 \% \mathrm{CI}=1.01-1.21)$ and $37-40(\mathrm{OR}=1.10$, $95 \% \mathrm{CI}=1.01-1.20)$ with term low birth weight; and (4) an association of dibromoacetic acid analyzed as a continuous variable 
Summary of data on neural tube defects for selected DBPs.

\begin{tabular}{|c|c|c|c|c|c|}
\hline DBP exposure measure & In vivo positive studies & In vivo negative studies & $\begin{array}{l}\text { Embryo culture } \\
\text { positive studies }\end{array}$ & $\begin{array}{l}\text { Embryo culture-negative } \\
\text { studies }\end{array}$ & MOA data \\
\hline Chlorinated DW & - & $\begin{array}{l}\text { Human, DW epi (Hwang et al., 2002) } \\
\text { Human, DW, epi (Kallen and Robert, 2000) } \\
\text { Human, DW, epi (Magnus et al., 1999) }\end{array}$ & - & - & - \\
\hline Total Trihalomethanes & $\begin{array}{l}\text { Human, DW, epi (Klotz and } \\
\text { Pyrch, 1998, 1999) } \\
\text { Human, DW also } \\
\text { contaminated with } \\
\text { solvents, epi (Bove et al., } \\
\text { 1995) }\end{array}$ & $\begin{array}{l}\text { Human, DW, epi (Shaw et al., 2003) } \\
\text { Human, DW, epi (Dodds et al., 1999) }\end{array}$ & - & - & $\begin{array}{l}\text { Human, DW, epi: an association with neural } \\
\text { tube defects was seen only in the cases } \\
\text { where the mothers did not take daily } \\
\text { multivitamin or folate supplements during } \\
\text { the } 3 \text { months prior to pregnancy, and not } \\
\text { when vitamins or folate were taken (Klotz } \\
\text { and Pyrch, 1999). }\end{array}$ \\
\hline $\begin{array}{l}\text { Bromodichloromethane } \\
\text { (BDCM) }\end{array}$ & $\begin{array}{l}\text { Human, DW, epi (Dodds } \\
\text { and King, 2001) }\end{array}$ & $\begin{array}{l}\text { Human, Dw, epi (Shaw et al., 2003) } \\
\text { Human, DW, epi (Klotz and Pyrch, 1998) } \\
\text { SD rat, G-corn oil (Ruddick et al., 1983) } \\
\text { SD rat, rabbit, DW (Christian et al., } \\
\text { 2001a) }\end{array}$ & - & - & $\begin{array}{l}\text { Rabbit, DW, limited data suggest BDCM } \\
\text { reaches placental and fetus (Christian et al., } \\
\text { 2001b). Generally, toxicity may be } \\
\text { mediated through metabolism to reactive } \\
\text { and toxic intermediates (ILSI, 1999). }\end{array}$ \\
\hline Dibromochloromethane & - & $\begin{array}{l}\text { Human, DW, epi (Shaw et al., 2003) } \\
\text { SD rat, G-corn oil (Ruddick et al., 1983) } \\
\text { ICR Swiss mouse, DW (Borzelleca and } \\
\text { Carchman, 1982) }\end{array}$ & - & - & $\begin{array}{l}\text { Generally, toxicity may be mediated } \\
\text { through metabolism to reactive and toxic } \\
\text { intermediates (ATSDR, 2003; ILSI, 1999). }\end{array}$ \\
\hline Bromoform & $\begin{array}{l}\text { Slightly suggestive data: } \\
\text { CD-1 mouse, G-aqueous, } \\
\text { exencephaly in one pup at } \\
\text { each of two high dose } \\
\text { groups (Narotsky et al., } \\
\text { 2001) }\end{array}$ & SD rat, G-corn oil (Ruddick et al., 1983) & - & - & $\begin{array}{l}\text { Generally, toxicity may be mediated } \\
\text { through metabolism to reactive and toxic } \\
\text { intermediates (ATSDR, 2003; ILSI, 1999). }\end{array}$ \\
\hline Chloroform & - & $\begin{array}{l}\text { Human, DW, epi (Dodds and King, 2001) } \\
\text { Human, DW, epi (Klotz and Pyrch, 1998) } \\
\text { SD rat, G-corn oil (Ruddick et al., 1983) } \\
\text { ICR Swiss mouse, DW (Borzelleca and } \\
\text { Carchman, 1982) } \\
\text { SD rat, rabbit, G-corn oil (Thompson } \\
\text { et al., 1974) } \\
\text { Wistar rat, Inhal. (Baeder and Hoffmann, } \\
\text { 1988, 1991a,b) } \\
\text { CF-1 mice, Inhal. (Murray et al., 1979) } \\
\text { SD rats, Inhal. (Schwetz et al., 1974) }\end{array}$ & - & $\begin{array}{l}\text { SD rat, day } 10.5 \text { ( } 12-15 \text { somites), diffuse } \\
\text { cell death, including neuroepithelium of } \\
\text { neural tube, but no effect on closure of } \\
\text { neural tube; effects may be due to loss of } \\
\text { yolk sac vascularization (Brown- } \\
\text { Woodman et al., 1998). }\end{array}$ & $\begin{array}{l}\text { At end of single 4-hour inhalation exposure } \\
\text { on GD 17, fetal to maternal chloroform } \\
\text { concentration ratio was 0.316; fetal } \\
\text { concentration was not related to position in } \\
\text { uterus (Withey and Karpinski, 1985). } \\
\text { Generally, toxicity may be mediated } \\
\text { through metabolism to reactive and toxic } \\
\text { intermediates (ILSI, 1999; U.S. EPA, 2001). }\end{array}$ \\
\hline Total haloacetic acids & - & Human, DW, epi (Klotz and Pyrch, 1999) & - & - & - \\
\hline Monobromoacetic acid & - & $\begin{array}{l}\text { Suggestive data: (not litter-based): } \\
\text { LE rat, G-water (Randall et al., 1991) }\end{array}$ & $\begin{array}{l}\text { CD-1 mouse, day } 8 \text { ( } 3-6 \text { somites), also } \\
\text { heart, pharyngeal arch and eye defects } \\
\text { (Hunter et al., 1996) }\end{array}$ & - & - \\
\hline Monochloroacetic acid & - & $\begin{array}{l}\text { SD rat-DW, MTD not achieved (Johnson } \\
\text { et al., 1998) } \\
\text { Suggestive data (not litter-based): } \\
\text { LE rat, G-water (Smith et al., 1990) }\end{array}$ & $\begin{array}{l}\text { CD-1 mouse, day } 8 \text { ( } 3-6 \text { somites), also } \\
\text { heart and pharyngeal arch defects } \\
\text { (Hunter et al., 1996) }\end{array}$ & 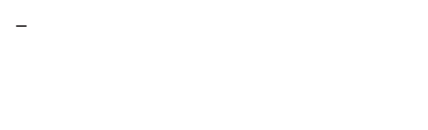 & 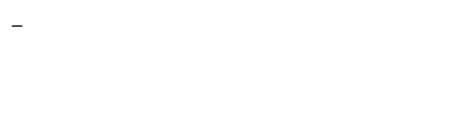 \\
\hline Dibromoacetic acid (DBA) & - & - & $\begin{array}{l}\text { CD-1 mouse, day } 8 \text { ( } 3-6 \text { somites), also } \\
\text { heart, pharyngeal arch and eye defects } \\
\text { (Hunter et al., 1996) } \\
\text { SD rat, day } 9.5(0-1 \text { somites), also } \\
\text { visceral arch hypoplasia and heart and } \\
\text { eye defects (Andrews et al., 2004) }\end{array}$ & $\begin{array}{l}\text { CD-1 mouse, day } 8 \text { ( } 3-6 \text { somites), } \\
\text { prosencephalic and pharyngeal arch } \\
\text { hypoplasia; heart and eye defects } \\
\text { (Hunter et al., 2006b) }\end{array}$ & $\begin{array}{l}\text { SD rat, DW, parent compound reaches } \\
\text { placenta, amniotic fluid and fetus (Christian } \\
\text { et al., 2001b) } \\
\text { Was dose additive with BCA and/or DCA on } \\
\text { development of rat embryo in culture } \\
\text { (Andrews et al., 2004) }\end{array}$ \\
\hline
\end{tabular}


Dichloroacetic acid (DCA)

Slightly suggestive data:

CD-1 mouse, G-water.

LE rat, G-water, eye defects (Smith et al., 1992a)

pup each at highest and 4th

highest dose levels

(Narotsky et al., 1996)
CD-1 mouse, day 8 (3-6 somites), also heart, pharyngeal arch and eye defects (Hunter et al., 1996 ${ }^{\mathrm{b}}, 2006 \mathrm{~b}$ )

SD rat, day 10 (4-7 somites), may be secondary to decreased yolk sac

circulation, also poor survival;

prosencephalic hypoplasia, eye defects, and decreased yolk sac diameter more sensitive (Saillenfait et al., 1995)

Suggestive data:

SD rat, day 9.5 (0-1 somites)

(malformations stated to be similar to

those from dibromoacetic acid in same

study) (Andrews et al., 2004)
SD rat, DW, but looked only at brain on Suggestive data:

CD-1 mouse, day 8 (3-6 somites),

PND 5 (NTP, National Toxicology

Program, 1998a)

D-1 mouse, day 8 (3-6 somites), neur

tube defects NS but small sample size, hypoplasia;

also prosencephalic and pharyng

hypoplasia; heart and ey

SD rat day 9.5 (0-1 somites)

malformations stated to be similar to

(malformat to

study) (Andrews et al., 2004)
Inhibited neural crest cell migration in

cultured explants from rat and mouse

embryos (Andrews et al., 2001; Hunter et

al., 2001)

Did not induce apoptosis in mouse embryo culture (Ward et al., 2000)

s more potent than its metabolites in

mouse embryo culture (Hunter and

Rogers, 1999)

F rat, G, antagonistic interaction for

resortions, cardiac and total viscera

malformations with TCA (Smithet al. 1991,

dose additive with DBA and/or BCA on development of rat embryo in culture

(Andrews et al., 2004)

LE rat, G, at 48 hours after dosing of dams with 1 - and $2-\left({ }^{14} \mathrm{C}\right)$-labeled DCA, ${ }^{14} \mathrm{C}$ levels were higher in embryos than in maternal plasma, and were present mainly as C2 (the dichloromethyl C), indicating a metabolite (Roth et al., 1991).

DCA has multiple effects in intermediary metabolism, particularly from inhibition of the kinase that inactivates mitochondrial pyruvate dehydrogenase (Crabb et al.

1981; Smith et al., 1992a; Stacpoole, 1989).

DCA-induced malformations in cultured

DCA-re embryos are not primarly due to

mertive oxygen speces (Huter et

2006).

DCA induces apoptosis in mouse embryos, including in the heart (Ward et al., 2000).

DCA did not inhibit neural crest cell

migration in culture (Andrews et al., 2001;

Hunter et al., 2001).

Has similar potency to its metabolites in

mouse embryo culture (Hunter and Rogers,

1999)

Was dose additive with DBA and/or DCA on development of rat embryo in culture

(Andrews et al., 2004)

Inhibited neural crest cell migration in cultured explants from rat and mouse embryos

(Andrews et al., 2001; Hunter et al., 2001)

Induces apoptosis in mouse embryos (Ward et al., 2000)

Metabolites of BCA were much less potent than BCA in mouse embryo culture (Hunter than BCA in mouse

and Rogers, 1999).

$B C A$ caused changes in gene expression in

mouse embryo culture (Karoly et al., 2004)

including genes networked with Akt

(protein kinase B) (Hunter et al., 2005). 
Dibromoacetonitrile

Chloroacetonitrile (CAN)

1,1,3,3,-Tetrachloropropanone -

Chlorine dioxide-disinfected DW

Chlorine dioxide
SD rat-DW, MTD not achieved, looked only at brain at PND 5 (NTP, National Toxicology Program, 1998c)

LE rat, G-water, eye defects

(Smith et al., 1989a)

SD rat, DW (Johnson et al., 1998)

SD rat, G-water (Fisher et al., 2001)

SD rat, DW, MTD not achieved, examined CD-1 mouse, day 8 (3-6 somites), yolk external malformations at PND 1,3,5 and sac defects at same concentration as

brain malformations at PND 5 (NTP, neural tube defects; also prosencephalic brain man

Human, DW, epi (Klotz and Pyrch, 1999)

LE rat, G-tricap (Smith et al., 1989b)

LE rat, G-tricap (Smith et al., 1988)

LE rat, G-corn oil, also G-tricap but

only one dose (Christ et al., 1996) eye defects (Hunter et al., 2006a)

CD-1 mouse, day 8 (3-6 somites), yolk CD-1 mouse, day 8 (3-6 somites), yolk sac defects at same concentration as NS neural tube defects, also prosencephalic hypoplasia, and heart, pharyngeal arch and eye defects (Hunter et al., 2006a) cardiac, pharyngeal arch and eye defects

(D-1 mouse, day 8 (3-6 somites), also cardiac, pharyngeal arch and eye
(D-1 mouse, day 8 (3-6 somites), also
SD rat, day 10 (4-7 somites),

LE rat, G, antagonistic interaction with DCA on et al., 1995

-

malformations (Smith et al., 1991, 1992b)

Has similar potency to its metabolites in mouse embryo culture (Hunter and Rogers, 1999)

LE rat, G-tricap (Christ et al., 1995)

CF-1 mouse, rabbit, G-corn oil (John et al., 1982)

Human, DW, epi (Kallen and Robert,

2000)

Rat, DW, but only 6-8 dams/dose

(Suh et al., 1983)

Rat, DW, but examined external

malformations during lactational period

(Carlton et al., 1991)

Metabolism to cyanide does not appear to account for developmental toxicity (Christ et al., 1995; Smith et al., 1988).

Metabolism to cyanide does not appear to account for developmental toxicity (Christ et al., 1995; Smith et al., 1988).

LE rat, G, accumulation of radioactivity in maternal liver and in fetus from 2-3 daily doses of ${ }^{14} \mathrm{C}$-TCAN was higher for the trichloromethyl of carbon (C2) than the cyano carbon. Accunulation in enbryos was higher with (Gorratin ve

Metabolism to cyanide does not appear to account for developmental toxicity (Chris et al., 1995; Smith et al., 1988).

Metabolism to cyanide does not appear to account for developmental toxicity (Christ et al., 1995; Smith et al., 1988)

Metabolism to cyanide does not appear to account for developmental toxicity (Christ et al., 1995; Smith et al., 1988).

Generally, toxicity is considered due to oxidative properties (U.S. EPA, 2000b).

Decreased the levels of circulating

thyroxine in monkeys and rats, and in developmental study in rats, possibly though oxidation of dietary iodide in the gastrointestinal tract, resulting in reactive species that iodinate organic matter to form potentially thyroid inhibitory compounds (Bercz et al., 1986; Orme et al., 1985) 
Table 4 (continued)

\begin{tabular}{|c|c|c|c|c|c|}
\hline DBP exposure measure & In vivo positive studies & In vivo negative studies & $\begin{array}{l}\text { Embryo culture } \\
\text { positive studies }\end{array}$ & $\begin{array}{l}\text { Embryo culture-negative } \\
\text { studies }\end{array}$ & MOA data \\
\hline Chlorite & - & $\begin{array}{l}\text { SD rat, DW, but only 6-8 dams/dose, MTD } \\
\text { not achieved (Suh et al., 1983) } \\
\text { Rabbit, DW, MTD may not have been } \\
\text { achieved (Harrington et al., 1995). } \\
\text { SD rat, DW, also maternal toxicity (body } \\
\text { weight loss and hemolysis) and greatly } \\
\text { decreased water and food intake (Couri } \\
\text { et al., 1982) } \\
\text { LE rat, DW, but examined external } \\
\text { malformations postnatally (Carlton and } \\
\text { Smith, 1985; Carlton et al., 1987) }\end{array}$ & - & 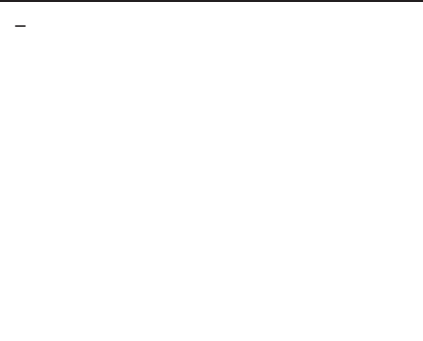 & $\begin{array}{l}\text { Generally, toxicity is considered due to } \\
\text { oxidative properties (U.S. EPA, 2000b). }\end{array}$ \\
\hline Chloral hydrate & - & $\begin{array}{l}\text { SD rat, DW (Johnson et al., 1998) } \\
\text { D-1 mouse, DW, only five dams/dose, } \\
\text { examined external malformations } \\
\text { postnatally (Kallman et al., 1984) }\end{array}$ & - & $\begin{array}{l}\text { SD rat, day } 10 \text { ( } 4-7 \text { somites), hypoplasia } \\
\text { of prosencephalon, pericardial } \\
\text { dilatation, eye defects, decreased yolk } \\
\text { sac diameter (Saillenfait et al., 1995) }\end{array}$ & $\begin{array}{l}\text { The metabolite trichloroethanol has } \\
\text { sedative effects. Other metabolites are } \\
\text { trichloroacetic and possibly small amounts } \\
\text { of dichloroacetic acid (U.S. EPA, 2000c). }\end{array}$ \\
\hline Dichloromethane & - & $\begin{array}{l}\text { LE rat, Inhal. (Hardin and Manson, 1980) } \\
\text { SD rat, Swiss Webster mouse, Inhal. } \\
\text { (Schwetz et al., 1975) } \\
\text { F344 rat, G-corn oil, examined } \\
\text { postnatally for external malformations } \\
\text { and if dead with no external } \\
\text { malformations, then for soft tissue } \\
\text { malformations (Narotsky and Kavlock, } \\
\text { 1995) }\end{array}$ & - & $\begin{array}{l}\text { SD rat, } 10.5 \text { days ( } 12-15 \text { somites) } \\
\text { craniofacial but not cardiac, but effects } \\
\text { may be due to severe effect on yolk sac } \\
\text { vascularization (Brown-Woodman et } \\
\text { al., 1998) }\end{array}$ & $\begin{array}{l}\text { Generally, toxicity may be due to P450 } \\
\text { metabolism to a reactive intermediate and } \\
\text { carbon monoxide, and to direct conjugation } \\
\text { of dichloromethane with GSH to form a } \\
\text { bioactive product. Also, the parent } \\
\text { compound may enter cell membranes and } \\
\text { thereby interfere with signal transmission } \\
\text { (ATSDR, 2000). }\end{array}$ \\
\hline Bromomethane & - & $\begin{array}{l}\text { RIV-TOX rat, G-peanut oil (Peters et al., } \\
\text { 1981) } \\
\text { Wistar rat, Inhal. (Sikov et al., 1981) } \\
\text { Rabbit, Inhal., MTD not achieved (Sikov et } \\
\text { al., 1981) } \\
\text { Rabbit, Inhal. (Breslin et al., 1990) }\end{array}$ & - & - & $\begin{array}{l}\text { Generally, toxicity may be due to the } \\
\text { alkylating (methylating) properties of } \\
\text { bromomethane (ATSDR, 1992; Vogel and } \\
\text { Nivard, 1994). }\end{array}$ \\
\hline
\end{tabular}

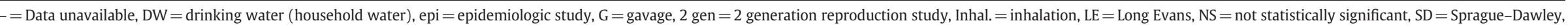
tricap $=$ tricaprylin.

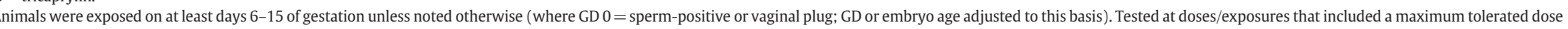
(MTD) unless otherwise noted.

${ }^{\mathrm{b}}$ Hunter et al. (1996) classified prosencephalic hypoplasia and neural tube closure defects together under the category neural tube defects. 
Table 5

Summary of data on low birth weight/intrauterine growth retardation for selected DBPS ${ }^{a}$.

\begin{tabular}{|c|c|c|c|c|c|}
\hline DBP exposure measure & In vivo positive studies & $\begin{array}{l}\text { In vivo negative } \\
\text { studies }\end{array}$ & $\begin{array}{l}\text { Embryo culture } \\
\text { positive studies }\end{array}$ & $\begin{array}{l}\text { Embryo culture- } \\
\text { negative studies }\end{array}$ & MOA data \\
\hline Chlorinated DW & $\begin{array}{l}\text { Equivocal data: } \\
\text { Human, DW, epi (Kallen and Robert, } \\
\text { 2000) and Human, DW, epi (Kanitz } \\
\text { et al., 1996) }\end{array}$ & $\begin{array}{l}\text { Human, DW, epi } \\
\text { (Jaakkola et al., 2001) }\end{array}$ & - & - & - \\
\hline Total trihalomethanes & $\begin{array}{l}\text { Human, DW, epi (Hoffman et al., 2008) } \\
\text { Human, DW, epi (Lewis et al., 2006) } \\
\text { Human, DW, epi (Wright et al., 2003, } \\
\text { 2004) } \\
\text { Human, DW, epi (Gallagher et al., 1998) } \\
\text { Human, DW also contaminated with } \\
\text { solvents, epi (Bove et al., 1995) } \\
\text { Equivocal: }\end{array}$ & $\begin{array}{l}\text { Human, DW, epi } \\
\text { (Yang et al., 2007) } \\
\text { Human, DW, epi } \\
\text { (Hinckley et al., 2005) } \\
\text { Human, DW, epi } \\
\text { (Porter et al., 2005) } \\
\text { Human, DW, epi } \\
\text { (Dodds et al., 1999) }\end{array}$ & - & - & $\begin{array}{l}\text { Maternal exposure to total trihalomethanes resulted in an increased } \\
\text { risk of intrauterine growth retardation only in newborns with a } \\
\text { variant CYP2E1 gene; the mother's CYP2E1 was not associated with } \\
\text { this outcome, and a 5,10-methylenetetrahydrofolate reductase gene } \\
\text { variant in newborns or mothers also was not associated with this } \\
\text { outcome (Infante-Rivard, 2004). }\end{array}$ \\
\hline $\begin{array}{l}\text { Bromodichloromethane } \\
\text { (BDCM) }\end{array}$ & $\begin{array}{l}\text { Human, DW, epi (Toledano et al., 2005) } \\
\text { Human, DW, epi. (Wright et al., 2004) }\end{array}$ & $\begin{array}{l}\text { Human, DW, epi } \\
\text { (Porter et al., 2005) } \\
\text { Human, DW, epi } \\
\text { (Hinckley et al., 2005) } \\
\text { Human, DW, epi } \\
\text { (Kramer et al., 1992) } \\
\text { SD rat, rabbit, DW } \\
\text { (Christian et al., } \\
\text { 2001a) } \\
\text { SD rat, G-corn oil } \\
\text { (Ruddick et al., 1983) } \\
\text { SD rat, DW (NTP, } \\
\text { National Toxicology } \\
\text { Program, 1998b) } \\
\text { F344 rat, G-aqueous } \\
\text { (Bielmeier et al., } \\
\text { 2004) } \\
\text { F344 rat, G-corn oil or } \\
\text { aqueous (Narotsky et } \\
\text { al., 1997a) }\end{array}$ & - & - & $\begin{array}{l}\text { Rabbit, DW, limited data suggest BDCM reaches placenta and fetus } \\
\text { (Christian et al., 2001b). Generally, toxicity may be mediated through } \\
\text { metabolism to reactive and toxic intermediates (ILSI, 1999). }\end{array}$ \\
\hline Dibromochloromethane & - & $\begin{array}{l}\text { Human, DW, epi } \\
\text { (Porter et al., 2005) } \\
\text { Human, DW, epi } \\
\text { (Hinckley et al., 2005) } \\
\text { Human, DW, epi } \\
\text { (Kramer et al., 1992) } \\
\text { SD rat, G-corn oil } \\
\text { (Ruddick et al., 1983) } \\
\text { SD rat, DW (NTP, } \\
\text { National Toxicology } \\
\text { Program, 1996) }\end{array}$ & - & - & $\begin{array}{l}\text { Generally, toxicity may be mediated through metabolism to reactive } \\
\text { and toxic intermediates (ATSDR, 2003; ILSI, 1999). }\end{array}$ \\
\hline Bromoform & - & $\begin{array}{l}\text { Human, DW, epi } \\
\text { (Porter et al., 2005) } \\
\text { Human, DW, epi } \\
\text { (Kramer et al., 1992) } \\
\text { SD rat, G-corn oil } \\
\text { (Ruddick et al., 1983) } \\
\text { CD-1 mouse, G-corn }\end{array}$ & - & - & $\begin{array}{l}\text { Generally, toxicity may be mediated through metabolism to reactive } \\
\text { and toxic intermediates (ATSDR, 2003; ILSI, 1999). }\end{array}$ \\
\hline
\end{tabular}




\section{DBP exposure measure}

In vivo positive studies

In vivo negative

In vivo neg
studies

Embryo culture

positive studies

Embryo culture-

negative studies

(NTP, National

1989)

Chloroform

Human, DW, epi (Kramer et al., 1992) May be secondary to maternal effects the following: SD rat, G-corn oil

(Ruddick et al., 1983) Human, DW, epi

uman, DW, epi 2001)

SD rat, day 10.5 (12-15 somites), may be due to loss of yolk sac

vascularization

SD rat, G-corn oil (Thompson et al., (Klotz and Pyrch,

1974)

1998)

Wistar rat, Inhal (Baeder and

Hoffmann, 1988, 1991a,b)

CD-1 (ICR) mous

(NTP, National

Toxicology Program,

SD rat, Inhal. (Schwetz et al., 1974) 1988)

CF-1 mouse, Inhal. (Murray et al., 1979) Human, DW, epi

(Hoffman et al., 2008)

Total haloacetic acids

Monobromoacetic acid

Monochloroacetic acid

Dibromoacetic acid (DBA)

Human, DW, epi (Porter et al., 2005)

(Hinckley et al., 2005)

Human, DW, epi, suggestive (Porter et

al., 2005)

LE rat, G-water, may be secondary to

E rat, G-water, may be seconday to

Human, DW, epi

(Porter et al., 2005)

SD rat-DW, MTD not

group (Johnson et al.

group (

LE rat, G-water

(Smith et al., 1990)

Human, DW, epi (Hinckley et al., 2005) Human, DW, epi

(Porter et al., 2005)

CD-1 mouse, G-water, may be secondary to maternal effects SD rat, DW, 2-gen (Christian et al., 2002b)

CD-1 mouse, day 8 (3-6 somites) (Hunter et al., 1996) (Narotsky et al., 1996)

Human, DW, epi, suggestive (Porter et

t al., 1996) al., 2005)

May be secondary to maternal effects in the following:

LE Rat, G-water (Smith et al., 1992a) SD rat, day 10 (4-7 somites), possibly secondary to effects on yolk sac (Saillenfait et al., 1995) SD rat, day 9.5 (0-1 somites) (Andrews et al., 2004)

At end of single 4-hour inhalation exposure on GD 17, fetal to maternal chloroform concentration ratio was 0.316; fetal concentration was not related to position in uterus (Withey and Karpinski, 1985).

Generally, toxicity may be mediated through metabolism to reactive and toxic intermediates (ILSI, 1999; U.S. EPA, 2001).

SD rat, DW, parent compound reaches placenta, amniotic fluid and fetus (Christian et al., 2001b).

Was dose additive with BCA and/or DCA on development of rat embryo in culture (Andrews et al., 2004)

Did not induce apoptosis in mouse embryo culture (Ward et al., 2000) Is more potent than its metabolites in mouse embryo culture (Hunter and Rogers, 1999)

LE rat, G, antagonistic interaction with TCA for resorptions and cardiac and total visceral malformations (Smith et al., 1991, 1992b)

Was dose additive with DBA and/or BCA on development of rat embryo in culture (Andrews et al., 2004)

LE rat, G, at 48 hours after dosing of dams with 1 - and $2-\left({ }^{14} \mathrm{C}\right)$-labeled DCA, ${ }^{14} \mathrm{C}$ levels were higher in embryos than in maternal plasma, and were present mainly as $\mathrm{C} 2$ (the dichloromethyl C), indicating a metabolite (Roth et al., 1991).

DCA has multiple effects in intermediary metabolism, particularly from inhibition of the kinase that inactivates mitochondrial pyruvate dehydrogenase (Crabb et al., 1981; Smith et al., 1992a; Stacpoole, 1989).

DCA induces apoptosis in mouse embryos (Ward et al., 2000).

Has similar potency to its metabolites in mouse embryo culture (Hunter and Rogers, 1999) 
Tribromoacetic acid

Trichloroacetic acid (TCA)

Dibromochloroacetic acid

Bromodichloroacetic acid

Total haloacetonitriles Dichloroacetonitrile

Trichloroacetonitrile (TCAN)

LE rat, G-tricap (Smith et al., 1989b) LE rat, G-tricap, may be secondary to maternal effects (Smith et al., 1987) LE rat, G-tricap (Smith et al., 1988)

May be secondary to maternal effects in the following: LE rat, G-tricap (Smith et al. 1987) and LE Rat, G-comn oil (Christ et al., 1996)

Bromochloroacetonitrile LE Rat, G-tricap (Christ et al, 1995)

\section{Dibromoacetonitrile}

Chloroacetonitrile

1,1,3,3,-Tetrachloropropanon

rat, G-tricap, may be secondary to maternal effects (Smith et al., 1987)

Chlorine dioxide-disinfected Human, DW, epi (Kanitz et al., 1996) DW

Chlorine dioxide

SD rat, DW, but maternal body weight

not reported (Mobley et al., 1990)
SD rat-DW, MTD not achieved (NTP,

Program, 1998c

CD-1 mouse, day 8 (3-6 somites) (Hunter et al., 1996)

Human, DW, epi
(Wright et al., 2004)

(Saillenfait et al., 1995)

SD rat, DW (Johnson CD-1 mouse, day 8 (3-6 somites)

et al., 1998) (Hunter et al., 1996)

SD rat, DW, MTD not

achieved (NTP,

National Toxicology

Program, 2000)

Narotsky et al., $\quad$ (Hunter et al., 2006a)

(Hunter et al., 2006a)
National Toxicolog

D-1 mouse, G-water CD-1 mouse, day 8 (3-6 somites)

CD-1 mouse, day 8 (3-6 somites) -

.

SD rat, DW, MTD not

achieved (NTP,

National Toxicology

Program, 1997)

CF-1 mouse, rabbit,

G-corn oil (John et al.,

1982)

Human, DW, epi

(Kallen and Robert,

2000)

MTD not achieved in SD rat, DW (O)ing. al., 1985)
Was dose additive with DBA and/or DCA on development of rat embryo in culture (Andrews et al., 2004)

Induces apoptosis in mouse embryos (Ward et al., 2000)

Metabolites of BCA were much less potent than BCA in mouse embryo culture (Hunter and Rogers, 1999).

BCA caused changes in gene expression in mouse embryo culture (Karoly et al., 2004).

LE rat, G, antagonistic interaction with DCA for resorptions and cardiac and total visceral malformations (Smith et al., 1991, 1992b) Has similar potency to its metabolites in mouse embryo culture (Hunter and Rogers, 1999)

Metabolism to cyanide does not appear to account for developmental
toxicity (Christ et al., 1995; Smith et al., 1988).
Metabolism to cyanide does not appear to account for developmental
toxicity (Christ et al., 1995; Smith et al., 1988).
LE rat, G, accumulation of radioactivity in maternal liver and in fetus
from 2-3 daily doses of ${ }^{14} \mathrm{C}-\mathrm{TCAN}$ was higher for the trichloromethyl
carbon (C2) than the cyano carbon. Accumulation in embryos was
higher with tricaprylin vehicle than corn oil vehicle (Gordon et al.,
1991).
Metabolism to cyanide does not appear to acco
toxicity (Christ et al., 1995; Smith et al., 1988).

Metabolism to cyanide does not appear to account for developmental toxicity (Christ et al., 1995; Smith et al., 1988).

Generally, toxicity is considered due to oxidative properties (U.S. EPA, 2000b) 
Table 5 (continued)

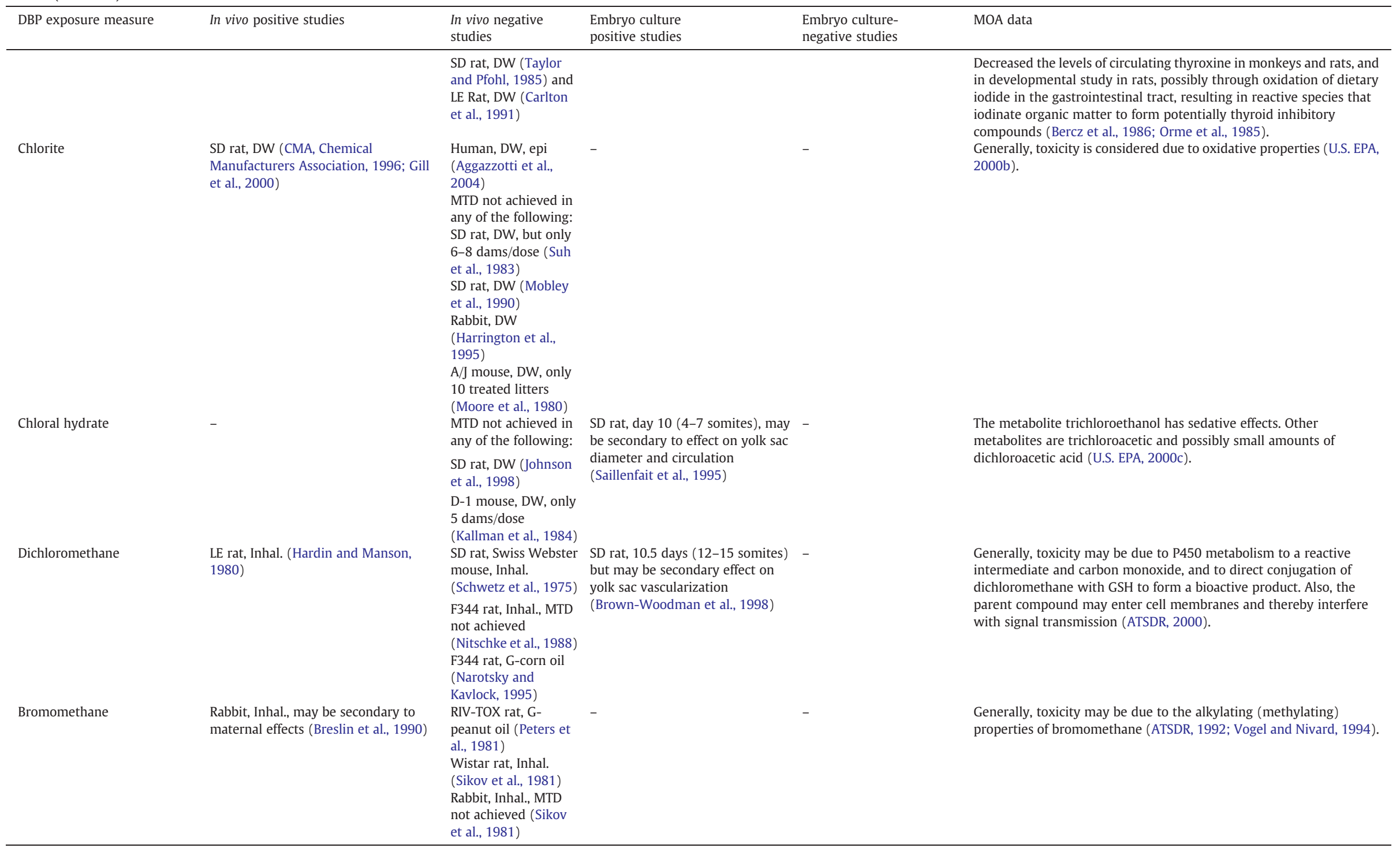

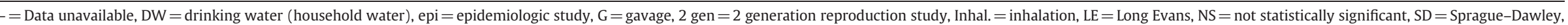
tricap $=$ tricaprylin.

exposed on at least days 6-15 of gestation unless noted otherwise (where GD $0=$ sperm-positive or vaginal plug; GDs or embryo age adjusted to this basis). Tested at doses/exposures that included a maximum tolerated dose (MTD) unless otherwise noted. 
in gestation weeks $25-28(\mathrm{OR}=1.06,95 \% \mathrm{CI}=1.01-1.12)$ with intrauterine growth retardation; (5) an association between dichloroacetic acid exposure at $\geq 8 \mu / \mathrm{L}(\mathrm{OR}=1.28,95 \% \mathrm{CI}=1.08-1.51)$ or to trichloroacetic acid at $\geq 6 \mu / \mathrm{L}(\mathrm{OR}=1.19,95 \% \mathrm{CI}=1.01-1.41)$ during the third trimester with intrauterine growth retardation.

Thus, the trihalomethanes and the haloacetic acids, both the classes and also some of the individual compounds, have been associated with intrauterine growth retardation and low birth weight in humans. Results are fairly consistent across the epidemiologic studies especially for total trihalomethanes and intrauterine growth retardation with all but one of the studies reporting relative risks in excess of 1.1. However, some of these results are not statistically significant and most are small in magnitude. These findings likely result from limited exposure assessment data and other study limitations which can decrease statistical power inhibiting the ability to detect risk small in magnitude and assess dose-response relationships.

As summarized in Table 5, developmental and reproductive studies of the individual DBPs in experimental animals have generally reported no adverse effects on fetal or newborn body weight or have reported adverse effects that may be secondary to maternal effects, including decreased maternal body weight gain, liver lesions, and clinical signs of toxicity. The exceptions are trichloroacetic acid; dichloro-, trichloro-, and bromochloroacetonitrile; chlorite; and dichloromethane, for which the fetal body weight effects appear to be relatively sensitive as compared with maternal effects. The studies in cultured mouse and rat embryos also reported growth retardation, often in the presence of adverse effects on the yolk sac (decreased diameter and circulation), and were inconsistent in whether and how they reported effects on the yolk sac, such that interpretation of these studies is problematic.

In summary, although a number of recent epidemiology studies have raised concerns regarding an association of low birth weight or intrauterine growth retardation with exposure to DBPs, the available in vivo and in vitro data are inadequate to outline key steps in an MOA for this effect.

\section{Conclusions}

Although an understanding of the MOA for an adverse developmental outcome is needed for a component-based risk assessment, such detailed knowledge typically is rare for developmental toxicants (Faustman et al., 2006; NRC, National Research Council, 2000), and, as presented in this paper, for the DBPs. A major reason is the complexity and plasticity of development. The need for understanding at different levels of biological organization and processes including cell migration, proliferation, and differentiation also complicates the study and interpretation of data relevant to developmental MOA (Faustman et al., 2006; NRC, National Research Council, 2000).

Our review and evaluation of the literature focused on 24 developmentally toxic DBPs and four adverse developmental outcomes associated with DBP exposure in humans. A plausible MOA is delineated for one of these outcomes, spontaneous abortion, which was associated with total trihalomethane exposure and with bromodichloromethane exposure in epidemiologic studies (Savitz et al., 1995; Waller et al., 1998). The available data seem to indicate that the target tissue is maternal and that the MOA may involve a hormonal disruption of pregnancy. It is reasonably well established for one of the trihalomethanes, bromodichloromethane, based on studies in rats in vivo and in human and rat tissues in vitro. Some MOA data were available for the other three outcomes (cardiovascular defects, neural tube defects, and low birth weight or small for gestational age), but the data were inadequate for any DBP to define key steps and clearly associate key steps (define a MOA) for those outcomes. Thus, to conduct a component-based health risk assessment of the developmentally toxic DBPs, further development of risk assessment methods is needed to assess the possibility that they may act by similar or dissimilar MOAs. MOA-based risk assessments provide a better understanding of dose-response in the region of low response than do risk assessments based only on assumptions of similarity or dissimilarity of MOA.

\section{Acknowledgments}

We gratefully acknowledge the many helpful comments we received from Drs. Jason Lambert and Belinda Hawkins (US EPA/NCEA). We also thank the peer reviewers who refereed this article for the journal.

\section{References}

Aggazzotti, G., Righi, E., Fantuzzi, G., Biasotti, B., Ravera, G., Kanitz, S., Barbone, F., Sansebastiano, G., Battaglia, M.A., Leoni, V., Fabiani, L., Triassi, M., Sciacca, S., Collaborative Group for the Study of Chlorinated Drinking Waters and Pregnancy., 2004. Chlorination by-products (CBPs) in drinking water and adverse pregnancy outcomes in Italy. J. Water Health 2 (4), 233-247.

Andrews, J.E., Nichols, H., Schmid, J., Hunter, E.S., 2001. Inhibition of neural crest cell migration by the water disinfection by-products dichloro-, dibromo- and bromochloroacetic acid. Toxicologist. 60 (1), 217.

Andrews, J.E., Nichols, H.P., Schmid, J.E., Mole, L.M., Hunter III, E.S., Klinefelter, G.R., 2004. Developmental toxicity of mixtures: the water disinfection by-products dichloro-, dibromo- and bromochloro acetic acid in rat embryo culture. Reprod. Toxicol. 19 (1), 111-116.

ATSDR (Agency for Toxic Substances and Disease Registry), 1992. Toxicological profile for bromomethane. Agency for Toxic Substances and Disease Registry, Atlanta, GA

ATSDR (Agency for Toxic Substances and Disease Registry), 2000. Toxicological profile for methylene chloride. Agency for Toxic Substances and Disease Registry, Atlanta, GA

ATSDR (Agency for Toxic Substances and Disease Registry), 2003. Toxicological profile for bromoform/dibromochloromethane. Draft for public comment (Update). Agency for Toxic Substances and Disease Registry, Atlanta, GA.

ATSDR (Agency for Toxic Substances and Disease Registry), 2004. Guidance manual for the assessment of joint toxic action of chemical mixtures. Agency for Toxic Substances and Disease Registry, Atlanta, GA.

Baeder, C., Hoffmann, T., 1988. Initial Submission: Inhalation Embryotoxicity Study of Chloroform in Wistar Rats. Final. With attachments and cover letter dated 02/21/ 92. Hoechst Aktiengesellschaft, Frankfort Am. Main: Pharma Res. Toxicol. Pathol. EPA/OTS Doc\#88-920001208. Report No. 88.0961. TSCA 8E Submission, OTS0000635.

Baeder, C. Hoffmann, T., 1991a. Initial Submission-Chloroform: Supplementary Inhalation Embryotoxicity Study in Wistar Rats. Final. With attachments and cover letter dated 12/ 24/91. NTIS/OTS0535017 (TSCA 8E submission). EPA/OTS Doc\#88-920000566. September 12, 1991. Performed by Hoechst Aktiengesellschaff, Germany, Sponsored by Hoechst AG and Dow Europe SA. Report No. 91.0902.

Baeder, C. Hoffmann, T., 1991b. Amendment No. 1 to Report No. 91.0902-Chloroform: Supplementary Inhalation Embryotoxicity Study in Wistar Rats. With cover letter dated 06/25/93. NTIS/OTS0535017-1 (TSCA 8E submission). EPA/OTS Doc\#89930000184. Performed by Hoechst Aktiengesellschaff, Germany, Sponsored by Hoechst AG and Dow Europe SA. Report No. 92.1047.

Bercz, J.P., Jones, L.L., Harrington, R.M., Bawa, R., Condie, L., 1986. Mechanistic aspects of ingested chlorine dioxide on thyroid function: impact of oxidants on iodide metabolism. Environ. Health Perspect. 69, 249-255.

Bielmeier, S.R., Best, D.S., Guidici, D.L., Narotsky, M.G., 2001. Pregnancy loss in the rat caused by bromodichloromethane. Toxicol. Sci. 59 (2), 309-315.

Bielmeier, S.R., Best, D.S., Narotsky, M.G., 2002. Strain comparison of endocrine response in rats to bromodichloromethane (BDCM) during pregnancy. Toxicologist. 66 (1-S), 374

Bielmeier, S.R., Best, D.S., Narotsky, M.G., 2004. Serum hormone characterization and exogeneous hormone rescue of bromodichloromethane-induced pregnancy loss in the F344 rat. Toxicol. Sci. 77, 101-108.

Bielmeier, S.R., Murr, A.S., Best, D.S., Harrison, R.A., Pegram, R.A., Goldman, J.M., Narotsky, M.G., 2007. Effects of bromodichloromethane on ex vivo and in vitro luteal function and bromodichloromethane tissue dosimetry in the pregnant F344 rat. Toxicol. In Vitro 21, 91-928.

Borzelleca, J.F., Carchman, RA., 1982. Effects of Selected Organic Drinking Water Contaminants on Male Reproduction. U.S. Environmental Protection Agency, Health Effects Research Laboratory, Research Triangle Park, NC. EPA/600/1-82/009. PB82-259847.

Bove, F.J., Fulcomer, B.C., Klotz, J.B., Smart, J.E., Dufficy, E.M., Savin, J.E., 1995. Public drinking water contamination and birth outcomes. Am. J. Epidemiol. 141 (9), 850-862.

Bove, F., Shim, Y., Zeitz, P., 2002. Drinking water contaminants and adverse pregnancy outcomes: a review. Environ. Health Perspect. 110 (Suppl 1), 61-74.

Breslin, W.J., Zublotny, C.L., Brabley. G.J., Lomax, L.G., 1990. Methyl Bromide Inhalation Teratology Study in New Zealand White Rabbits. Toxicology Research Laboratory, Health and Environmental Studies, Dow Chemical Co., Midland, MI. EPAMRID41580401. Study K-00681-033. OTS Number 8EHQ-1189-0844 S. The Toxicology Research Laboratory. Methyl Bromide Industry Panel, DPR Vol. 123-127. \#95930.

Brown-Woodman, P.D.C., Hayes, L.C., Huq, F., Herlihy, C., Picker, K., Webster, W.S., 1998. In vitro assessment of the effect of halogenated hydrocarbons: chloroform, dichloromethane, and dibromoethane on embryonic development of the rat. Teratology 57 (6), 321-333. 
Carlton, B.D., Smith, M.K., 1985. Reproductive effects of alternate disinfectants and their by-products. Water Chlorination: Chemistry, Environmental Impact and Health Effects. Proceedings of the Fifth Conference on Water Chlorination-Environmental Impact and Health Effects. Lewis Publishers, Chelsea, Williamsburg, Virginia, pp. 295-305. June 3-8, 1984.

Carlton, B.D., Habash, D.L., Basaran, A.H., George, E.L., Smith, M.K., 1987. Sodium chlorite administration in Long-Evans rats: reproductive and endocrine effects. Environ. Res. 42, 238-245.

Carlton, B.D., Basaran, A.H., Mezza, L.E., George, E.L., Smith, M.K., 1991. Reproductive effects in Long-Evans rats exposed to chlorine dioxide. Environ. Res. 56 (2), $170-177$.

Cedergren, M.I., Selbing, A.J., Lofman, O., Kallen, B.A., 2002. Chlorination byproducts and nitrate in drinking water and risk for congenital cardiac defects. Environ. Res. 89 (2), 124-130.

Chen, J., Douglas, G.C. Thirkill, T.L., Lohstroh, P.N., Bielmeier, S.R., Narotsky, M.G., Best, D.S., Harrison, R.A., Natarjan, K., Pegram, R.A., Overstreet, J.W., Lasley, B.L., 2003. Effect of bromodichloromethane on chorionic gonadotrophin secretion by human placental trophoblast cultures. Toxicol. Sci. 76 (1), 75-82.

Chen, J., Thirkill, T.L., Lohstroh, P.N., Bielmeier, S.R., Narotsky, M.G., Best, D.S., Harrison, R.A., Natarajan, K., Pegram, R.A., Overstreet, J.W., Lasley, B.L., Douglas, G.C., 2004. Bromodichloromethane inhibits human placental trophoblast differentiation. Toxicol. Sci. 78 (1), 166-174.

Chisholm, K., Cook, A., Bower, C., Weinstein, P., 2008. Risk of birth defects in Australian communities with high brominated disinfection by-product levels. Environ. Health Perspect. 116 (9), 1267-1273.

Christ, S.A., Read, E.J., Stober, J.A., Smith, M.K., 1995. The developmental toxicity of bromochloro-acetonitrile in pregnant Long-Evans rats. Int. J. Environ. Health Res. 5 (2), $175-188$.

Christ, S.A., Stober, J.A., Smith, K., 1996. Developmental effects of trichloroacetonitrile administered in corn oil to pregnant Long-Evans rats. J. Toxicol. Environ. Health 47 (3), 233-247.

Christian, M.S., York, R.G., Hoberman, A.M., Diener, R.M., Fisher, L.C., 2001a. Oral (drinking water) developmental toxicity studies of bromodichloromethane (BDCM) in rats and rabbits. Int. J. Toxicol. 20 (4), 225-237.

Christian, M.S., York, R.G., Hoberman, A.M., Diener, R.M., Fisher, L.C., Gates, G.A., 2001b. Biodisposition of dibromoacetic acid (DBA) and bromodichloromethane (BDCM) administered to rats and rabbits in drinking water during rangefinding reproduction and developmental toxicity studies. Int. J. Toxicol. 20 (4), 239-253.

Christian, M.S., York, R.G., Hoberman, A.M., Fisher, L.C., Brown, W.R., 2002a. Oral (drinking water) two-generation reproductive toxicity study of bromodichloromethane (BDCM) in rats. Int. J. Toxicol. 21 (2), 115-146.

Christian, M.S., York, R.G., Hoberman, A.M., Frazee, J., Fisher, L.C., Brown, W.R., Creasy, D.M. 2002b. Oral (drinking water) two-generation reproductive toxicity study of dibromoacetic acid (DBA) in rats. Int. J. Toxicol. 21 (4), 237-276.

CMA (Chemical Manufacturers Association). 1996. Sodium Chlorite: Drinking Water Rat Two Generation Reproductive Toxicity Study. Chemical Manufacturers Association. Quintiles Report Ref. CMA/17/96.

Couri, D., Miller Jr., C.H., Bull, R.J., Delphia, J.M., Ammar, E.M., 1982. Assessment of maternal toxicity, embryotoxicity and teratogenic potential of sodium chlorite in Sprague-Dawley rats. Environ. Health Perspect. 46, 25-29.

Crabb, D.W., Yount, E.A., Harris, R.A., 1981. The metabolic effects of dichloroacetate. Metabolism 30 (10), 1024-1039.

Cummings, A.M., Hedge, J.M., 1998. Dibromoacetic acid does not adversely affect early pregnancy in rats. Reprod. Toxicol. 12 (4), 445-448.

Dodds, L., King, W.D., 2001. Relations between trichloromethane compounds and birth defects. Occup. Environ. Med. 58 (7), 443-446.

Dodds, L., King, W., Woolcott, C., Pole, J., 1999. Trihalomethanes in public water supplies and adverse birth outcomes. Epidemiology 10 (3), 233-237.

Dodds, L., King, W., Allen, A.C., Armson, B.A., Fell, D.B., Nimrod, C., 2004. Trihalomethanes in public water supplies and risk of stillbirth. Epidemiology 15 (2), 179-186.

Epstein, D.L., Nolen, G.A., Randall, J.L., Christ, S.A., Read, E.J., Stober, J.A., Smith, M.K., 1992. Cardiopathic effects of dichloroacetate in the fetal Long-Evans rat. Teratology 46 (3), 225-235.

Faustman, E.M., Ponce, R.A., Seeley, M.R., Whittaker, S.G., 2006. Experimental approaches to evaluate mechanisms of developmental toxicity. In: Hood, R.D. (Ed.), Handbook of Developmental Toxicology. CRC Press, Inc., Baca Raton, pp. 15-80.

Feron, V.J., Groten, J.P., 2002. Toxicological evaluation of chemical mixtures. Food Chem. Toxicol. 40 (6), 825-839.

Fisher, J.W., Channel, S.R., Eggers, J.S., Johnson, P.D., MacMahon, K.L., Goodyear, C.D. Sudberry, G.L., Warren, D.A., Latendresse, J.R., Graeter, L.J., 2001. Trichloroethylene, trichloroacetic acid, and dichloroacetic acid: do they affect fetal rat heart development? Int. J. Toxicol. 20 (5), 257-267.

Gallagher, M.D., Nuckols, J.R., Stallones, L., Savitz, D.A., 1998. Exposure to trihalomethanes and adverse pregnancy outcomes. Epidemiology 9 (5), 484-489.

Gill, M.W., Swanson, M.S., Murphy, S.R., Bailey, G.P., 2000. Two-generation reproduction and developmental neurotoxicity study with sodium chlorite in the rat. J. Appl. Toxicol. 20 (4), 291-303.

Gordon, D.A., Wessendarp, T.K., Crocker, W., Smith, M.K., Roth, A.C., 1991. Comparative absorption and distribution of radiolabeled trichloroacetonitrile (TCAN) in pregnant rats from corn oil (CO) and tricaprylin (TCAP) vehicles. Teratology 43 (5), 427.

Graves, C.G., Matanoski, G.M., Tardiff, R.G., 2001. Weight of evidence for an association between adverse reproductive and developmental effects and exposure to disinfection by-products: a critical review. Regul. Toxicol. Pharmacol. 34 (2), 103-124.

Hardin, B.D., Manson, J.M., 1980. Absence of dichloromethane teratogenicity with inhalation exposure in rats. Toxicol. Appl. Pharmacol. 52, 22-28.
Harrington, R.M., Romano, R.R., Irvine, L., 1995. Developmental toxicity of sodium chlorite in the rabbit. J. Am. Coll. Toxicol. 14 (2), 108-118.

Hill, A.B., 1965. The environment and disease: association or causation? Proc. Roy. Soc Med. 58, 295-300.

Hinckley, A.F., Bachand, A.M., Reif, J.S., 2005. Late pregnancy exposures to disinfection byproducts and growth-related birth outcomes. Environ. Health Perspect. 113 (12), 1803-1813.

Hoffman, C.S., Mendola, P., Savitz, D.A., Herring, A.H., Loomis, D., Hartmann, K.E., Singer, P.C., Weinberg, H.S., Olshan, A.F., 2008. Drinking water disinfection by-product exposure and fetal growth. Epidemiology 19 (5), 729-737.

Hongve, D., Andersen, T., 1991. Factors determining the light absorption of aquatic humic substances. Finn. Humus News 3, 209-214.

Hunter III, E.S., Rogers, E.H., 1999. Dysmorphogenic effects of three metabolites of haloacetic acids in mouse embryo culture. Teratology 59 (6), 402.

Hunter III, E.S., Rogers, E.H., Schmid, J.E., Richard, A., 1996. Comparative effects of haloacetic acids in whole embryo culture. Teratology 54 (2), 57-64.

Hunter III, E.S., Smith, J., Andrews, J., 2001. Haloacetic acids and kinase inhibitors perturb mouse neural crest cells in vitro. Teratology 63 (6), 255.

Hunter III, E.S., Blanton, M., Karoly, E., Rosen, M., 2005. Exposure to a P13kinase inhibitor produces dysmorphogenesis in neurulation-staged mouse embryos in culture. Teratol. Soc. Abstr. 289, 301.

Hunter III, E.S., Rogers, E., Blanton, M., Richard, A., Chernoff, M., 2006a. Bromochlorohaloacetic acids: Effects on mouse embryos in vitro and QSAR considerations. Reprod. Toxicol. 21 (3), 260-266.

Hunter III, E.S., Blanton, M.R., Rogers, E.H., Mole, M.L., Andrews, J., Chernoff, N., 2006b. Short-term exposures to dihaloacetic acids produce dysmorphosgenesis in mouse conceptuses in vitro. Reprod. Toxicol. 22, 443-448.

Hunter III, E.S., Rogers, E.H., Blanton, M.R., 2006c. Minimal role for reactive oxygen species in dichloroacetic acid-induced dysmorphology in mouse whole embryo culture. Birth Defects Res. Clin. Mol. Teratol. 76 (5), 326

Hwang, B.F., Magnus, P., Jaakkola, J.J.K., 2002. Risk of specific birth defects in relation to chlorination and the amount of natural organic matter in the water supply. Am. J. Epidemiol. 156 (4), 374-382.

Hwang, B.F., Jaakkola, J.J.K., Guo, H.R., 2008. Water disinfection by-products and the risk of specific birth defects: a population-based cross-sectional study in Taiwan. Environ. Health 7, 23-34.

ILSI (International Life Sciences Institute, 1999. Mechanistic Research on Disinfection By-products. Report from an ILSI Workshop, October 15, 1998. International Life Sciences Institute, Washington, DC

Infante-Rivard, C., 2004. Drinking water contaminants, gene polymorphisms, and fetal growth. Environ. Health Perspect. 112 (11), 1213-1216.

Institute of Medicine, 1998. Dietary Reference Intakes. National Academy Press, Washington, DC, pp. 196-206. 212-215, 240-260, 269-270; App M. 523-526.

IPCS (International Programme on Chemical Safety). 2005. IPCS Framework for Analyzing the Relevance of a Cancer Mode of Action for Humans. Public Review Draft. April. International Programme on Chemical Safety. Available at http://www. who.int/ipcs/methods/harmonization/areas/frameworktextreview.pdf.

IRDC (International Research and Development Corporation). 1976. Dichloromethane and Ninety Day Oral Toxicity Study in Rats. (Reproduction and ninety day oral toxicity study in rats). Performed by International Research and Development Corporation. Submitted by General Electric Company to U.S. EPA, Office of Toxic Substances under TSCA 8(d). Fiche No. OTS0205887.

Jaakkola, J.J., Magnus, P., Skrondal, A., Hwang, B.F., Becher, G., Dybing, E., 2001. Foetal growth and duration of gestation relative to water chlorination. Occup. Environ. Med. 58 (7), 437-442.

John, J.A., Murray, F.J., Quast, J.F., Keeler, P.A., Schwetz, B.A., Staples, R.E., 1982. 1,1,3,3Tetrachloroacetone: teratogenicity study in mice and rabbits. Fundam. Appl. Toxicol. 2 (5), 220-225.

Johnson, P.D., Dawson, B.V., Goldberg, S.J., 1998. Cardiac teratogenicity of trichloroethylene metabolites. J. Am. Coll. Cardiol. 32 (2), 540-545.

Kallen, B.A.J., Robert, E., 2000. Drinking water chlorination and delivery outcome-a registry-based study in Sweden. Reprod. Toxicol. 14, 303-309.

Kallman, M.J., Kaempf, G.L., Balster, R.L., 1984. Behavioral toxicity of chloral in mice: an approach to evaluation. Neurobehav. Toxicol. Teratol. 6 (2), 137-146.

Kanitz, S., Franco, Y., Patrone, V., Caltabellotta, M., Raffo, E., Riggi, C., Timitilli, D., Ravera, G., 1996. Association between drinking water disinfection and somatic parameters at birth. Environ. Health Perspect. 104 (5), 516-520.

Karoly, E.D., Schmid, J.E., Blanton, M.R., Hunter, E.S., 2004. Altered gene expression of mouse embryo cultures exposed to bromochloroacetic acid. Birth Defects Res. A Clin. Mol. Teratol. 70 (5), 250.

Kim, H.J., Bruckner, J.V., Dallas, C.E., Gallo, J.M., 1990a. Effect of dosing vehicles on the pharmacokinetics of orally administered carbon tetrachloride in rats. Toxicol. Appl Pharmacol. 102 (1), 50-60.

Kim, H.J., Odend'hal, S., Bruckner, J.V., 1990b. Effect of dosing vehicles on the acute hepatotoxicity of carbon tetrachloride in rats. Toxicol. Appl. Pharmacol. 102 (1), 34-49.

Klinefelter, G.R., Hunter III, E.S., Narotsky, M.G., 2001. Reproductive and developmental toxicity associated with disinfection by-products in drinking water. In: Craun, G.F. Hauchman, S.F., Robinson, D.E. (Eds.), Microbial Pathogens and Disinfection ByProducts in Drinking Water: Heath Effects and Management of Risks. ILSI Press, Washington, pp. 309-324.

Klotz, J.B., Pyrch, L.A., 1998. A case-control study of neural tube defects and drinking water contaminants. U.S. Department of Health and Human Services, Public Health Service, Agency for Toxic Substances and Disease Registry, Atlanta, GA. NTIS PB98111644.

Klotz, J.B., Pyrch, L.A., 1999. Neural tube defects and drinking water disinfection byproducts. Epidemiology 10 (4), 383-390. 
Kramer, M.D., Lynch, C.F., Isacson, P., Hanson, J.W., 1992. The association of waterborne chloroform with intrauterine growth retardation. Epidemiology 3 (5), 407-413.

Krasner, S.W., Pastor, S., Chinn, R., Sclimenti, M.J., Weinberg, H.S., Richardson, S.D., 2001 The Occurrence of a New Generation of DBPs (Beyond the ICR). Presented at the American Water Works Association Water Quality Technology Conference, Nashville, TN, November 11-15, 2001.

Krasner, S.W., Weinberg, H.S., Richardson, S.D., Pastor, S.J., Chinn, R., Sclimenti, M.J., Onstad, G.D., Thruston Jr, A.D., 2006. Occurrence of a new generation of disinfection byproducts. Environ. Sci. Technol. 40, 7175-7178.

Lewis, C., Suffet, I.H., Ritz, B., 2006. Estimated effects of disinfection by-products on birth weight in a population served by a single water utility. Am. J. Epidemiol. 163 (1), 38-47.

Lewis, C., Suffet, I.H., Hoggatt, K., Ritz, B., 2007. Estimated effects of disinfection byproducts on preterm birth in a population served by a single water utility. Environ. Health Perspect. 115 (2), 290-295.

Lilly, P.D., Simmons, J.E., Pegram, R.A., 1994. Dose-dependent vehicle differences in the acute toxicity of bromodichloromethane. Fundam. Appl. Toxicol. 23, 132-140.

Lipscomb, J.C., El-Demerdash, E., Ahmed, A.E., 2009. Haloacetonitriles: metabolism and toxicity. Rev. Environ. Contam. Toxicol. 198, 169-200.

MacLehose, R.F., Savitz, D.A., Herring, A.H., Hartmann, K.E., Singer, P.C., Weinberg, H.S 2008. Drinking water disinfection by-products and time to pregnancy. Environ. Health Perspect. 19 (3), 451-458.

Magnus, P., Jaakkola, J.J., Skrondal, A., Alexander, J., Becher, G., Krogh, T., Dybing, E., 1999. Water chlorination and birth defects. Epidemiology 10 (5), 513-517.

Meek, M.E., Bucher, J.R., Cohen, S.M., Dellarco, V., Hill, R.N., Lehman-McKeeman, L.D., Longfellow, D.G., Pastoor, T., Seed, J., Patton, D.E., 2003. A framework for human relevance analysis of information on carcinogenic modes of action. Crit. Rev. Toxicol. 33 (6), 591-653.

Miles, A.M., Singer, P.C., Ashley, D.L., Lynberg, M.C., Mendola, P., Langlois, P.H., Nuckols, J.R., 2002. Comparison of trihalomethanes in tap water and blood. Environ. Sci. Technol. 36, 1692-1698.

Miltner, R.J., Rice, E.W., Stevens, A.A., 1990. Pilot-Scale Investigation of the Formation and Control of Disinfection Byproducts. 1990 Annual Conference Proceedings, AWWA Annual Conference, Cincinnati, OH. 2, pp. 1787-1802.

Mobley, S.A., Taylor, D.H., Laurie, R.D., Pfohl, R.J., 1990. Chlorine dioxide depresses T3 uptake and delays development of locomotor activity in young rats. In: Jolley, R.L. Condie, L.W., Johnson, J.D., Katz, S., Minear, R.A., Mattice, J.S., Jocobs, V.A. (Eds.), Water Chlorination: Chemistry, Environmental Impact and Health Effects, Vol. 6 Lewis Publications, Chelsea, pp. 347-360.

Moore, G.S., Calabrese, E.J., Leonard, D.A., 1980. Effects of chlorite exposure on conception rate and litters of A/J strain mice. Bull. Environ. Contam. Toxicol. 25 (5), 689-696.

Murray, F.J., Schwetz, B.A., McBride, J.G., Staples, R.E., 1979. Toxicity of inhaled chloroform in pregnant mice and their offspring. Toxicol. Appl. Pharmacol. 50 (3), 515-522.

Narotsky, M.G., Kavlock, R.J., 1995. A multidisciplinary approach to toxicological screening: II. Developmental toxicity. J. Toxicol. Environ. Health 45 (2), 145-171.

Narotsky, M.G., Laffan, S.B., 2004. Animal models for studying miscarriage: illustration with study of drinking water disinfection byproducts. Birth Defects Res. A Clin. Mol. Teratol. 70 (5), 283.

Narotsky, M.G., Hamby, B.T., Mitchell, D.S., Kavlock, R.J., 1992. Full-litter resorptions caused by low-molecular weight halocarbons in F-344 rats. Teratology 45, 472-473.

Narotsky, M.G., Hamby, B.T., Mitchell, D.S., Kavlock, R.J., 1993. Bromoform requires a longer exposure period than carbon tetrachloride to induce pregnancy loss in F-344 rats. Toxicologist. 13, 255

Narotsky, M.B., Hamby, B.T., Best, D.S., Hunter, E.S., 1996. In vivo developmental effects of dibromoacetic acid (DBA) and dichloroacetic acid (DCA) in mice. Teratology 53 (2) 96-97.

Narotsky, M.G., Pegram, R.A., Kavlock, R.J., 1997a. Effect of dosing vehicle on the developmental toxicity of bromodichloromethane and carbon tetrachloride in rats. Fundam. Appl. Toxicol. 40 (1), 30-36.

Narotsky, M.G., Brownie, C.F., Kavlock, R.J., 1997b. Critical period of carbon tetrachlorideinduced pregnancy loss in Fischer-344 rats, with insights into the detection of resorption sites by ammonium sulfide staining. Teratology 56, 252-261.

Narotsky, M.G., Best, D.S., Rogers, E.H., Hunter III, E.H., 2001. Developmental effects of disinfectant by-products bromoform, bromodichloromethane, bromodichloroac tetic acid, and bromochloroacetic acid in mice. Teratology 63 (6), 279.

Narotsky, M.G., Best, D.S., McDonald, A., Godin, E.A., Hunter III, E.S., Simmons, J.E., 2011. Pregnancy loss and eye malformations in offspring of F344 rats following gestational exposure to mixtures of regulated trihalomethanes and haloacetic acids. Reprod. Toxicol. 31 (1), 59-65.

Nieuwenhuijsen, M.J., Toledano, M.B., Eaton, N.E., Fawell, J., Elliott, P., 2000. Chlorination disinfection byproducts in water and their association with adverse reproductive outcomes: a review. Occup. Environ. Med. 57 (2), 73-85, doi:10.1136/oem.57.2.73.

Nieuwenhuijsen, M.J., Toledano, M.B., Bennett, J., Best, N., Hambly, P., de Hoogh, C., Wellesley, D., Boyd, P.A., Abramsky, L., Dattani, N., Fawell, J., Briggs, D., Jarup, L., Elliot, P., 2008. Chlorination disinfection by-products and risk of congenital anomalies in England and Wales. Environ. Health Perspect. 116 (2), 216-222.

Nitschke, K.D., Eisenbrandt, D.L., Lomax, L.G., Rao, K.S., 1988. Methylene chloride: twogeneration inhalation reproductive study in rats. Fundam. Appl. Toxicol. 11 (1), 60-67.

NRC (National Research Council, 2000. Mechanisms of developmental toxicity. Scientific Frontiers in Developmental Toxicology and Risk Assessment. National Research Council. National Academy Press, Washington, pp. 58-87.

NTP (National Toxicology Program). 1988. Chloroform: Reproduction and Fertility Assessment in CD-1 Mice when Administered by Gavage. National Toxicology Program, National Institute of Environmental Health Sciences, Research Triangle Park, NC. NTP-89-018.

NTP (National Toxicology Program). 1989. Bromoform: Reproduction and Fertility Assessment in Swiss CD-1 Mice when Administered by Gavage. National
Toxicology Program, National Institute of Environmental Health Sciences, Research Triangle Park, NC. NTP-89-068. PB89-169254.

NTP (National Toxicology Program). 1996. Final Report on the Short Term Reproductive and Developmental Toxicity of Chlorodibromomethane (CAS \#124-48-1) Administered in Drinking Water to Sprague-Dawley Rats. National Toxicology Program, National Institute of Environmental Health Sciences, Research Triangle Park, NC. NTPRDGT94007. PB97-111728.

NTP (National Toxicology Program). 1997. Final Report on the [Short Term] Reproductive [and Developmental Toxicity] of Dibromoacetonitrile (CAS \#325243-5) Administered in Diet [Drinking Water] to Sprague-Dawley Rats. National Toxicology Program, National Institute of Environmental Health Sciences, Research Triangle Park, NC. NTPRDGT94014. PB97-143127.

NTP (National Toxicology Program). 1998a. Short Term Reproductive and Developmental Toxicity Study of Bromochloroacetic Acid (CAS No. 5589-96-8) when Administered to Sprague-Dawley Rats in the Drinking Water. National Toxicology Program, National Institute of Environmental Health Sciences, Research Triangle Park, NC. NTPRDGT96001. PB98172414.

NTP (National Toxicology Program). 1998b. Final Report on the Short Term Reproductive and Developmental Toxicity of Bromodichloromethane (CAS \#7527-4) Administered in the Drinking Water to Sprague-Dawley Rats. National Toxicology Program, National Institute of Environmental Health Sciences, Research Triangle Park, NC. NTPRDGT94017. PB97-111262.

NTP (National Toxicology Program). 1998c. Final report on the short term reproductive and developmental toxicity of tribromoacetic acid (CAS No. 75-96-7) administered in drinking water to Sprague-Dawley rats. Research Triangle Park, NC: National Toxicology Program, National Institute of Environmental Health Sciences. NTPRDGT94009. PB98165111.

NTP (National Toxicology Program). 2000. Final Report on the Short Term Reproductive and Developmental Toxicity of Dibromochloroacetic Acid (CAS \#5278-95-5) Administered in Drinking Water to Sprague-Dawley Rats. National Toxicology Program, National Institute of Environmental Health Sciences, Research Triangle Park, NC. PB2000103420.

OECD (Organisation for Economic Co-operation and Development). 2001. OECD Guideline for the Testing of Chemicals. 414: Prenatal Developmental Toxicity Study. Available at http://www.new.sourceoecd.org/rpsv/periodical/p15_about. htm?jnlissn $=1607310 \mathrm{x}$.

Orme, J., Taylor, D.H., Laurie, R.D., Bull, R.J., 1985. Effects of chlorine dioxide on thyroid function in neonatal rats. J. Toxicol. Environ. Health 15 (2), 315-322.

Padmanabhan, R., 2006. Etiology, pathogenesis and prevention of neural tube defects. Congenit. Anom. 46, 555-567.

Peters, P.W.J., Verhoef, A., de Liefde, A., van Velsen, F.L. van Soolingen, J., de Geus, D., Danse, L.H.J., van Logten, M.J., 1981. Teratogenicity Study of Methyl Bromide Dosed Orally. Submitted by Ethyl Corporation to U.S. Environmental Protection Agency, Office of Toxic Substances. Fiche No. OTS0516089.

Porter, C.K., Putnam, S.D., Hunting, K.L., Riddle, M.R., 2005. The effect of trihalomethane and haloacetic acid exposure on fetal growth in a Maryland county. Am. J. Epidemiol. 162 (4), 334-344.

Randall, J.L., Christ, S.A., Horton Perez, P., Nolen, G.A., Read, E.J., Smith, M.K., 1991. Developmental effects of 2-bromoacetic acid in Long-Evans rat. Teratology. 43 (5), 454. (also an unpublished manuscript by Randall et al., 1992)

Richardson, S.D., 1998. Drinking water disinfection by-products. The Encyclopedia of Environmental Analysis and Remediation, Vol. 3. John Wiley \& Sons, New York, pp. 1398-1421.

Richardson, S.D., Thruston Jr., A.D., Caughran, T.V., Chen, P.H., Collette, T.W., Floyd, T.L., Schenck, K.M., Lykins Jr., B.W., 1999. Identification of new ozone disinfection byproducts in drinking water. Environ. Sci. Technol. 33, 3368-3377.

Richardson, S.D., Caughran, T.V., Poiger, T., Guo, Y., Crumley, F.G., 2000a. Application of DNPH derivatization with LC/MS to the identification of polar carbonyl disinfection by-products in drinking water. Ozone Sci. Engin. 22 (6), 653-675.

Richardson, S.D., Thruston Jr., A.D., Caughran, T.V., Chen, P.H., Collette, T.W., Schenck, K.M., Lykins Jr., B.W., Rav-Acha, C., Glezer, V., 2000b. Identification of new drinking water disinfection by-products from ozone, chlorine dioxide, chloramine, and chlorine. Water Air Soil Pollut. 123 (1), 95-102.

Richardson, S.D., Thruston Jr., A.D., Rav-Acha, C., Groisman, L., Popilevsky, I., Glezer, V. McKague, A.B., Plewa, M.J., Wagner, E.D., 2003. Tribromopyrrole brominated acids, and other disinfection by-products produced by the disinfection of drinking water rich in bromide. Environ. Sci. Technol. 37 (17), 3782-3793.

Richardson, S.D., Thruston, A.D., Jr, Krasner S.W., Weinberg, H.S., Miltner, R.J., Schenck, K.M., Narotsky, M.G., McKague, A.B., Simmons, J.E., 2008. Integrated disinfection byproducts mixtures research: comprehensive characterization of water concentrates prepared from chlorinated and ozonated/postchlorinated drinking water. J. Toxicol. Environ. Health A 71 (17), 1165-1186.

Rogers, J.M., Lau, C., Andrews, J.E., Chernoff, N., Thibodeaux, J.D., Barbee, B.D., Grey, B.E., 2005. Effect of varying maternal folate status and dietary folate intake on response to diverse developmental toxicants in the rat. Teratol. Soc. Abstr. 289, 314

Roth, A.C., Crocker, W., Wessendarp, T.K., Smith, M.K., Gordon, D.A., 1991. Dose related absorption and distribution of dichloroacetate (DCA) in pregnant Long-Evans rats. Teratology 43 (5), 428

Ruddick, J.A., Villeneuve, D.C., Chu, I., Valli, V.E., 1983. A teratological assessment of four trihalomethanes in the rat. J. Environ. Sci. Health B 18 (3), 333-349.

Saillenfait, A.M., Langonne, I., Sabate, J.P., 1995. Developmental toxicity of trichloroethylene, tetrachloroethylene and four of their metabolites in rat whole embryo culture. Arch. Toxicol. 70 (2), 71-82.

Savitz, D.A., Andrews, K.W., Pastore, L.M., 1995. Drinking water and pregnancy outcome in central North Carolina: source, amount, and trihalomethane levels. Environ. Health Perspect. 103 (6), 592-596. 
Savitz, D.A., Singer, P.C., Hartmann, K.E., Herring, A.J., Weinberg, H.S., 2005 Drinking Water Disinfection By-products and Pregnancy Outcome. AWWA Research Foundation, Denver, CO. Available at http://www.awwarf.org/ research/TopicsandProjects/execSum/PDFReports/91088F.pdf.

Savitz, D.A., Singer, P.C., Herring, A.H., Hartmann, K.E., Weinberg, H.W., Makarushka, C., 2006. Exposure to drinking water disinfection by-products and pregnancy loss. Am. J. Epidemiol. 164 (11), 1043-1051.

Schwetz, B.A., Leong, B.K., Gehring, P.J., 1974. Embryo- and fetotoxicity of inhaled chloroform in rats. Toxicol. Appl. Pharmacol. 28 (3), 442-451.

Schwetz, B.A., Leong, K.J., Gehring, P.J., 1975. The effect of maternally inhaled trichloroethylene, perchloroethylene, methyl chloroform, and methylene chloride on embryonal and fetal development in mice and rats. Toxicol. Appl. Pharmacol. 32 (1), 84-96.

Seed, J., Carney, E.W., Corley, R.A., Crofton, K.M., DeSesso, J.M., Foster, P.M., Kavlock, R., Kimmel, G., Klaunig, J., Meek, M.E., Preston, R.J., Slikker Jr., W., Tabacova, S., Williams, G.M., Wiltse, J., Zoeller, R.T., Fenner-Crisp, P., Patton, D.E., 2005. Overview: using mode of action and life stage information to evaluate the human relevance of animal toxicity data. Crit. Rev. Toxicol. 35, 663-672.

Shaw, G.M., Ranatunga, D., Quach, T., Neri, E., Correa, A., Neutra, R.R., 2003. Trihalomethane exposures from municipal water supplies and selected congenital malformations. Epidemiology 14, 191-199.

Sikov, M.R., Cannon, W.C., Carr, D.B., Miller, R.A., Montgomery, L.F., Phelps, D.W., 1981 Teratologic Assessment of Butylene Oxide, Styrene Oxide and Methyl Bromide. U. S. Department of Health and Human Services, National Institute for Occupational Safety and Health, Cincinnati, OH. DHHS (NIOSH) Publication No. 81-124. PB81168510.

Simmons, J.E., Richardson, S.D., Speth, T., Miltner, R.J., Rice, G., Schenck, K., Teuschler, L.K., 2002. Development of an research strategy for integrated technology-based toxicology studies on drinking water disinfection byproducts. Environ. Health Perspect. 110 (Supplement 6), 1013-1024.

Simmons, J.E., Teuscher, L.K., Gennings, C., Speth, T.F., Richardson, S.D., Miltner, R.J., Narotsky, M.G., Schenck, K.D., Hunter III, E.S., Hertzberg, R.C., Rice, G., 2004. Component-based and whole-mixture techniques for addressing the toxicity of drinking-water disinfectionbyproduct mixtures. J. Toxicol. Environ. Health A 67, 741-754.

Simmons, J.E., Richardson, S.D., Teuschler, L.K., Miltner, R.J., Speth, T.F., Schenck, K.M., Hunter III, E.S., Rice, G., 2008. Research issues underlying the four-lab study: integrated disinfection by-products mixtures research. J. Toxicol. Environ. Health A 71 (17), 1125-1132.

Smith, M.K., George, E.L., Zenjck, H., Manson, J.M., Stober, J.A., 1987. Developmental toxicity of halogenated acetonitriles: drinking water by-products of chlorine disinfection. Toxicology 46 (1), 83-93.

Smith, M.K., Randall, J.L., Tocco, D.R., York, R.G., Stober, J.A., Read, E.J., 1988. Teratogenic effects of trichloroacetonitrile in the Long-Evans rat. Teratology 38 (2), 113-120.

Smith, M.K., Randall, J.L., Read, E.J., Stober, J.A., 1989a. Teratogenic activity of trichloroacetic acid in the rat. Teratology 40 (5), 445-451.

Smith, M.K., Randall, J.L., Stober, J.A., Read, E.J., 1989b. Developmental toxicity of dichloroacetonitrile: a by-product of drinking water disinfection. Fundam. Appl. Toxicol. 12 (4), 765-772.

Smith, M.K., Randall, J.L., Read, E.J., Stober, J.E., 1990. Developmental effects of chloroacetic acid in the Long-Evans rat. Teratology. 41 (5), 593. (an unpublished manuscript by Randall et al., 1992)

Smith, M.K., Christ, S.A., Randall, J.L., Nolen, G.A., Read, E.J., Stober, J.A., 1991. Interaction study of chlorinated acetic acids in pregnant Long-Evans rats. Teratology 43 (5), 453-454.

Smith, M.K., Randall, J.L., Read, E.F., Stober, J.A., 1992a. Developmental toxicity of dichloroacetate in the rat. Teratology 46 (3), 217-223.

Smith, M.K., Weller, E., Chinchilli, V., Read, E.J., Christ, S.A., Randall, J.L., Kavlock, R.J., 1992b. Statistical analysis of a developmental toxicity interaction study. Teratology 45 (5), 488-489.

Sonich-Mullin, C., Fielder, R., Wiltse, J., Baetcke, K., Dempsey, J., Fenner-Crisp, P., Grant, D., Hartley, M., Knaap, A., Kroese, D., Mangelsdorf, I., Meek, E., Rice, J.M., Younes, M., 2001. IPCS conceptual framework for evaluating a mode of action for chemical carcinogenesis. Regul. Toxicol. Pharmacol. 34 (2), 146-152.

Stacpoole, P.W., 1989. The pharmacology of dichloroacetate. Metabolism 38 (11), 1124-1144.

Suh, D.H., Abdel-Rahman, M.S., Bull, R.J., 1983. Effect of chlorine dioxide and its metabolites in drinking water on fetal development in rats. J. Appl. Toxicol. 3 (2), 75-79.

Swan, S.H., Waller, K., 1998. Disinfection by-products and adverse pregnancy outcomes: what is the agent and how should it be measured? Epidemiology 9 (5), 479-481.

Swan, S.H., Waller, K., Hopkins, B., Windham, G., Fenster, L., Schaefer, C., Beutra, R.R., 1998. A prospective study of spontaneous abortion: Relation to amount and source of drinking water consumed in early pregnancy. Epidemiology 9 (12), 126-133.

Tardiff, R.G., Carson, M.L., Ginevan, M.E., 2006. Updated weight of evidence for an association between adverse reproductive and developmental effects and exposure to disinfection by-products. Regul. Toxicol. Pharmacol. 45 (2), 185-205.

Taylor, D.H., Pfohl, R.J., 1985. Effects of chlorine dioxide on the neurobehavioral development of rats. In: Jolley, R.L., Bull, R.J., Davis, W.P., Katz, S. (Eds.), Water Chlorination: Chemistry, Environmental Impact, and Health Effects. Lewis Publications, Chelsea, pp. 355-364.

Teuschler, L.K., Simmons, J.E., 2003. Approaching the toxicity of disinfection byproducts in drinking water as a mixtures problem. J. Am. Water Works Assoc. 95 (6), 131-138.

Teuschler, L.K., Rice, G.E., Wilkes, C.R., Lipscomb, J.C., Power, F.W., 2004. A feasibility study of cumulative risk assessment methods for drinking water disinfection byproduct mixtures. J. Toxicol. Environ. Health A 67 (8-10), 755-777.
Thompson, D.J., Warner, S.D., Robinson, V.B., 1974. Teratology studies on orally administered chloroform in the rat and rabbit. Toxicol. Appl. Pharmacol. 29 (3), 348-357.

Toledano, M.B., Nieuwenhuijsen, M.J., Best, N., Whitaker, H., Humbly, P., de Hoogh, C., Fawell, J., Jarup, L., Elliott, P., 2005. Relation of trihalomethane concentrations in public water supplies to stillbirth and birth weight in three water regions in England. Environ. Health Perspect. 113 (2), 225-232.

U.S. EPA (U.S. Environmental Protection Agency). 1986. Guidelines for the Health Risk Assessment of Chemical Mixtures. Fed. Reg. 51(185):34014-34025. Available at http://www.epa.gov/iris/backgr-d.htm.

U.S. EPA (U.S. Environmental Protection Agency). 1991. Guidelines for Developmental Toxicity Risk Assessment. U.S. Environmental Protection Agency, Risk Assessment Forum, Washington, DC. EPA/600/FR-91/001. Fed. Reg. 56(234):63798-63826. Available at http://www.epa.gov/iris/backgr-d.htm.

U.S. EPA (U.S. Environmental Protection Agency, 1998. Health Effects Test Guidelines OPPTS 870.3700 Prenatal Developmental Toxicity Study. U.S. Environmenta Protection Agency, Office of Prevention, Pesticides and Toxic Substances Washington, DC.

U.S. EPA (U.S. Environmental Protection Agency). 2000a. Supplementary Guidance for Conducting Health Risk Assessment of Chemical Mixtures. U.S. Environmental Protection Agency, Risk Assessment Forum, Washington, DC. EPA/630/R-00/002. Available at http://www.epa.gov/iris/backgr-d.htm

U.S. EPA (U.S. Environmental Protection Agency). 2000b. Toxicological Review of Chlorine Dioxide and Chlorite (CAS nos. 10049-04-4 and 7757-19-2) in Support of Summary Information on the Integrated Risk Information System (IRIS). U.S. Environmental Protection Agency, Washington, DC. EPA/635/R-00/007. Available at http://www.epa.gov/iris/index.html.

U.S. EPA (U.S. Environmental Protection Agency). 2000c. Toxicological Review of Chloral Hydrate (CAS nos. 302-17-0) in Support of Summary Information on the Integrated Risk Information System (IRIS). U.S. Environmental Protection Agency, Washington, DC. EPA/635/R-00/006. Available at http://www.epa.gov/iris/index. html.

U.S. EPA (U.S. Environmental Protection Agency). 2001. Toxicological Review of Chloroform (CAS nos. 67-66-3) in Support of Summary Information on the Integrated Risk Information System (IRIS). U.S. Environmental Protection Agency, Washington, DC. EPA/635/R-01/001. Available at http://www.epa.gov/iris/index. html.

U.S. EPA (U.S. Environmental Protection Agency). 2003. Framework for Cumulative Risk Assessment. U.S. Environmental Protection Agency, Risk Assessment Forum, Washington, DC. EPA/630/P-02/001F. Available at http://www.cfpub.epa.gov/ ncea/cfm/recordisplay.cfm?deid $=54944$.

U.S. EPA (U.S. Environmental Protection Agency). 2005. Guidelines for Carcinogen Risk Assessment. U.S. Environmental Protection Agency, Risk Assessment Forum, Washington, DC. EPA/630/P-03/001F. Available at http://www.epa.gov/iris/ backgr-d.htm.

U.S. EPA (U.S. Environmental Protection Agency). 2006. National Primary Drinking Water Regulations: Stage 2 Disinfectants and Disinfection Byproducts Rule; Final rule. 40 CFR parts 9, 141, and 142. Fed. Reg. 71(2):388-493. Available at http:// www.epa.gov/ogwdw/disinfection/stage2/index.html

U.S. FDA (U.S. Food and Drug Administration). 2000. Guidelines for Developmental Toxicity Studies. Section IV.C.9.b. In: Toxicological Principles for the Safety Assessment of Food Ingredients, Redbook 2000. U.S. Food and Drug Administration, Center for Food Safety and Applied Nutrition, Washington, DC. Available at http:// www.cfsan.fda.gov/ redbook/redivc9b.html.

Vogel, E.W., Nivard, M.J., 1994. The subtlety of alkylating agents in reactions with biological macromolecules. Mutat. Res. 305 (1), 13-32.

Waller, K., Swan, S.H., Delorenze, G., Hopkins, B., 1998. Trihalomethanes in drinking water and spontaneous abortion. Epidemiology 9 (2), 134-140.

Waller, K., Swan, S.H., Windham, G.C., Fenster, L., 2001. Influence of exposure assessment methods on risk estimates in an epidemiologic study of total trihalomethane exposure and spontaneous abortion. J. Expo. Anal. Environ. Epidemiol. 11 (6), 522-531.

Ward, K.W., Rogers, E.H., Hunter, E.S.I.I.I., 2000. Comparative pathogenesis of haloacetic acid and protein kinase inhibitor embryotoxicity in mouse whole embryo culture. Toxicol. Sci. 53 (1), 118-126.

Weinberg, H., 1999. Disinfection byproducts in drinking water: the analytical challenge. Anal. Chem. 71 (23), 801A-909A.I I.

Weinberg, H.S., Krasner, S.W., Richardson, S.D., Thruston Jr., A.D., 2002. The occurrence of disinfection by-products (DBPs) of health concern in drinking water: Results of a nationwide DBP occurrence study. U.S. Environmental Protection Agency, Athens, GA. Publication No. EPA/600/R-02/068. Available at http://www.epa.gov/ATHENS publications/reports/EPA_600_R02_068.pdf.

Withey, J.R., Karpinski, K., 1985. The fetal distribution of some aliphatic chlorinated hydrocarbons in the rat after vapor phase exposure. Biol. Res. Pregnancy Perinatol. 6 (2), 79-88.

Withey, J.R., Collins, B.T., Collins, P.B., 1983. Effect of vehicle on the pharmacokinetics and uptake of four halogenated hydrocarbons from the gastrointestinal tract of the rat. J. Appl. Toxicol. 3 (5), 249-253.

Wright, J.M., Schwartz, J., Dockery, D.W., 2003. Effect of trihalomethane exposure on fetal development. Occup. Environ. Med. 60, 173-180.

Wright, J.M., Schwartz, J., Dockery, D.W., 2004. The effect of disinfection by-products and mutagenic activity on birth weight and gestational duration. Environ. Health Perspect. 112, 920-925.

Yang, C.Y., Xiao, Z.P., Ho, S.C., Wu, T.N., Tsai, S.S., 2007. Association between trihalomethane concentrations in drinking water and adverse pregnancy outcome in Taiwan. Environ. Res. 104, 390-395. 